\title{
Neoinquisitorialismo processual penal e a contaminação do julgador com os atos de investigação: a burla interna no processo penal brasileiro como obstáculo ao contraditório
}

\author{
Criminal procedural neoinquisitorialism and the judger's \\ contamination with the acts of investigation: the internal burla in \\ brazilian criminal proceedings as obstacles to the contradictory
}

\author{
Marcos Eugênio Vieira Melo ${ }^{1}$ \\ Faculdade Raimundo Marinho - Maceió/AL, Brasil \\ marcos.evmelo@gmail.com \\ http://lattes.cnpq.br/6518709197337260 \\ http://orcid.org/0000-0001-5854-579X
}

\begin{abstract}
Resumo: Este artigo analisa a permanência da cultura inquisitória na América Latina e o peso da mentalidade inquisitória dentro do processo penal brasileiro, especialmente na fase preliminar, que trata do núcleo principal da formação probatória utilizada pelo julgador na sentença, no intuito de responder o seguinte problema: quais os principais obstáculos no processo penal brasileiro na contemporaneidade para que haja um julgamento efetivamente em contraditório? Para tanto, avalia-se por meio de estudo de doutrinas clássicas e contemporâneas as implicações na legitimação admitida pelo processo penal brasileiro, principalmente por meio do "jogo sujo" trazido pela brecha do artigo 155 do Código
\end{abstract}

1 Mestre em Ciências Criminais pela Pontifícia Universidade Católica do Rio Grande do Sul - PUCRS, Bolsista CAPES. Pós-Graduado em Processo Penal pelo Instituto de Direito Penal Económico e Europeu (IDPEE), da Faculdade de Direito da Universidade de Coimbra e o Instituto Brasileiro de Ciências Criminais (IBCCRIM). Membro do Grupo de Pesquisa Biopolítica e Processo Penal. Coordenador adjunto do Grupo de Estudos em Ciências Criminais e Direitos Humanos do IBCCRIM/AL. Assessor de Magistrado vinculado ao Tribunal de Justiça de Alagoas. Professor da graduação e pós-graduação da Faculdade Raimundo Marinho em Maceió/AL (FRM). 
de Processo Penal, que contamina o magistrado com o inquérito policial e em conjunto com significantes como "livre convencimento" e "verdade real" servem como obstáculos para que haja um julgamento fundado apenas em atos produzidos em contraditório e com a participação de todas as partes envolvidas no processo.

Palavras-Chave: Processo penal; Cultura inquisitória; Contraditório; Inquérito policial.

ABSTRACT: This article analyzes the permanence of the Inquisitory culture in Latin America and the weight of the Inquisitory mentality within the Brazilian criminal process, especially in the preliminary phase, which deals with the main nucleus of the probative formation used by the judge in the sentence, in order to answer the following problem: what are the main obstacles in the Brazilian criminal process today so that there is an effectively contradictory judgment? For this purpose, it is evaluated through the study of classical and contemporary criminal process doctrines the implications on the legitimacy admitted by the Brazilian criminal process, mainly through the "dirty game" brought by the breach of article 155 of the Code of Criminal Procedure, which contaminates the magistrate with the police inquiry and in conjunction with signifiers such as "free conviction" and "real truth" serve as obstacles to judgment based solely on contradictory acts and the participation of all parties involved in the process.

KeYwords: Criminal proceedings; Inquisitive culture; Contradictory; Police Inquiry.

SUMÁRIO: Introdução; 1. As permanências inquisitórias nos processos penais da América Latina; 2. O problema da expansão da investigação preliminar e a falácia do sistema bifásico: a construção do sujeito criminoso pelas polícias brasileiras; 3. A burla interna no processo penal brasileiro em desfavor do contraditório: a brecha no artigo 155 e o "jogo sujo" processual; Considerações Finais; Referências.

\section{INTRODUÇÃO}

Afere-se que o processo penal da américa latina foi inspirado no processo penal europeu e até os dias atuais sofre com os reflexos 
do período da inquisição, bem como do famigerado sistema misto do Code d'instruccion criminelle napoleônico. Do mesmo modo, desde a colonização e a formação da sociedade brasileira o autoritarismo e a mentalidade inquisitória estavam presentes e continuam impregnados em seus atores hodiernamente.

Esse procedimento fundado majoritariamente na fase de investigação que têm como características ser escrito e sigiloso, faz com que o processo seja mero espetáculo legitimante de "repetição" do que já está produzido, inviabilizando um contraditório em paridade de armas e colocando o julgador distante da formação probatória, fazendo-o atuar não como um garantidor dos direitos, mas como um mero legitimador do que foi produzido na fase de investigação.

Para que haja um julgamento com um efetivo contraditório é necessário que as provas sejam produzidas na audiência durante a fase processual, com respeito a imediação, com ambas as partes debatendo em paridade de armas e perante o julgador que irá julgar a causa, que deverá ser diferente daquele que atuou na fase de investigação.

O presente artigo tem como objetivo tratar de alguns dos principais obstáculos no Brasil para que ocorra um processo penal em que apenas atos produzidos durante as audiências e com a presença de todas as partes envolvidas possam ser utilizados pelos magistrados no momento em que forem sentenciar, ou, responder a pergunta-problema de quais são os principais obstáculos processuais no processo penal brasileiro para se ter um processo realmente oral e com um efetivo contraditório?

O primeiro tópico, portanto, tratará das permanências inquisitórias do processo penal desde a colonização europeia da américa latina até os dias atuais, que no campo processual instaurou o sistema misto que consagra a persecução como um sistema bifásico, com o peso de uma mentalidade inquisitória na fase de investigação em que a defesa tem muitas dificuldades de atuar e não existe um contraditório na formação probatória e nem uma fase intermediária antes do recebimento da denúncia, com a observância da defesa contrapor e refutar o que foi produzido na investigação.

No segundo tópico será analisado o problema da expansão da fase de investigação preliminar e os pormenores em relação à formação do inquérito policial e das instituições policiais, tratando-se 
dos seus problemas estruturais e de como isso influencia em toda a persecução penal.

Por último, o terceiro tópico tratar-se-á da falácia do sistema misto com a possiblidade do julgador utilizar essa fase para basear sua decisão condenatória legitimada pelo art. 155 do Código de Processo Penal, que abre espaço para que a fase de investigação seja utilizada para fundamentar o livre convencimento do magistrado.

\section{As PERMANÊNCIAS INQUISITÓRIAS NOS PROCESSOS PENAIS DA AmÉrica Latina}

Não se pode afirmar que o sistema inquisitório/autoritário está superado e que com a formalização de uma constituição democrática o sistema acusatório/democrático está em pleno vigor. Pelo contrário, não é fácil superar mais de 500 anos de inquisição, especialmente por ter sido um sistema tão bem elaborado e a serviço dos desígnios políticos de uma época que transcende no tempo por meio de renovações e ressignificações de conceitos ${ }^{2}$.

Dessa forma, algumas características da inquisição permanecem até os dias atuais nos processos penais contemporâneos, não somente através de leis e códigos inquisitoriais, mas principalmente na mentalidade dos atores jurídicos responsáveis pelos atos processuais e de parte da doutrina que propala alguns atributos processuais originários na inquisição como princípios do processo penal.

A América Latina, que teve seu processo originário dos países da Europa continental, sobretudo dos países ibéricos ${ }^{3}$, herdou essas ca-

2 Segundo Binder: "Nadie cambiará cinco siglos de sistema inquisitorial sin una gran batalla y una época de traumas. Lo contrario es mera ilusión o excusa conservadora. Sin embargo, una adecuada preparación del cambio, una firme concentración de fuerzas en los puntos neuralógicos y el sostenimiento del proyecto de transformacíon en el tiempo, mediante ajustes y una evaluación permanente, aparecen como herramientas imprescindibles para encarar el abandono del sistema inquisitivo" (BINDER, Alberto La fuerza de la Inquisición y la debilidad de la República. Política Criminal Bonaerense, n. 1, 2003, p. 8).

3 Para Nilo Batista o desejo de um ideal autoritário possibilitou que as práticas e dogmas disseminados pela inquisição colaborassem para a formação 
racterísticas inquisitórias em seus processos penais ${ }^{4}$. No Brasil, de forma genérica, a maior parte da legislação penal e processual penal que vigorou até sua independência estava prevista nas Ordenações portuguesas, mais especificamente no Livro V das Ordenações Filipinas 5 .

No século XIX a Europa continental iniciou uma série de medidas que reformaram seu sistema de processo penal. Em 1808 foi introduzido na França por Napoleão o Code d'Instruction Criminelle, que tentou se afastar do modelo inquisitorial da Ordonnance criminelle de 1670 e incorporar diversas ideias do modelo inglês de processo, porém acabou permanecendo em sua essência com o espírito do regime antigo e mantendo o status quo ${ }^{6}$.

Esse código foi por diversas razões pedra fundamental de reformas na Europa continental, que foi levado por reflexo político à América Latina. Ele trouxe uma situação paradoxal em relação ao tratamento do

da matriz do sistema criminal brasileiro (BATISTA, Nilo. Matrizes ibéricas do sistema penal brasileiro. Rio de Janeiro: Revan, 2000, p. 363).

4 "Guste o disguste, la historia política latinoamericana actual es uma continuación de los esquemas sócio-políticos de Europa continental, introducidos por los pueblos hispano-luso parlantes, conquistadores del territorio que, modernamente, denominamos Latinoamérica" (MAIER, Julio B. J. Situación de la justicia penal y problemas de los sistemas escritos. Revista de la Asociación de Ciencias Penales de Costa Rica, junio 1991, $\mathrm{n}^{\circ}$ 4, p. 2).

5 POLI, Camilin Marcie de. O Inquérito Policial e sua utilização na fase processual penal: (des)conformidade com o devido processo penal. 2015. 213 f. Dissertação (Mestrado em Direito) - Programa de Pós-Graduação em Direito, Setor de Ciências Jurídicas, Universidade Federal do Panará, Curitiba, 2015, p. 111. Segundo Marques, o Livro V das Ordenações Filipinas era cruel e arbitrário no que tange ao processo penal, com regras inquisitivas que se juntavam com um direito penal arcaico e assim formavam uma legislação criminal deveras ríspida (MARQUES, José Frederico. Tratado de direito processual penal. v. 1. São Paulo: Saraiva, 1980, p. 113-116).

6 LANGER, Máximo. Revolução no processo penal latino-americano: difusão de ideias jurídicas a partir da periferia. Revista da Faculdade de Direito da UFRGS, n. 37, p. 4-51, 2017, dez., p. 14. Segundo o autor: "Seguindo a tradição inquisitorial da Europa continental, o Code d'instruction criminelle estabeleceu uma investigação secreta e escrita pré-julgamento, na qual o réu tinha direitos muito limitados. No entanto, inspirado pelo modelo inglês, o Code também incorporou um julgamento oral e público" (LANGER, Máximo. Revolução no processo penal latino-americano: difusão de ideias jurídicas a partir da periferia. Revista da Faculdade de Direito da UFRGS, n. 37, p. 4-51, 2017, dez., p. 14). 
imputado: por um lado, na fase de investigação preparatória o acusado era tratado como um objeto, sem se inteirar dos atos cumpridos e nem de seu conteúdo, que eram escritos e secretos para ele e para o seu defensor; por outro lado, a fase de juízo era formada por um debate oral e público equiparado ao órgão acusador e garantida a sua defesa por um defensor técnico e a possibilidade de contraditório ${ }^{7}$.

Dessa forma, após a onda de independência dos Estados latino americanos entre 1810 e 1830, iniciou-se as discussões sobre os tipos de leis que seriam adotadas na construção desses Estados e o processo penal foi uma das questões centrais, em parte por causa das reformas dos processos penais europeus do século XIX. Apesar de conhecerem os processos ditos mais liberais advindos do continente europeu e dos Estados Unidos, as elites latino americanas seguiram inicialmente o modelo inquisitorial criado pela Igreja Católica e as monarquias absolutistas, porém rejeitando a tortura para obter confissões e limitando o sistema de provas legais ${ }^{8}$.

Com isso, de forma geral, o processo penal da América Latina foi dividido em duas fases principais: a fase de investigação (resumo ou instrução) e a fase de veredito ou sentença (plenário ou julgamento). Nessa época ambas as fases eram escritas e a espinha dorsal do processo eram os chamados dossiês ou expedientes que a polícia e o juiz de instrução reuniam. Esse instrumento documentava toda a atividade do processo, abarcando além das provas documentais as provas testemunhais, periciais etc., que seriam utilizadas pelos julgadores na fase de julgamento ${ }^{9}$.

7 MAIER, Julio B. J. Derecho procesal penal. Tomo I: fundamentos. Buenos Aires: Del Puerto, 2006, p. 350-354.

8 LANGER, Máximo. Revolução no processo penal latino-americano: difusão de ideias jurídicas a partir da periferia. Revista da Faculdade de Direito da UFRGS, n. 37, p. 4-51, 2017, dez., p. 13-15.

9 LANGER, Máximo. Revolução no processo penal latino-americano: difusão de ideias jurídicas a partir da periferia. Revista da Faculdade de Direito da UFRGS, n. 37, p. 4-51, 2017, dez., p. 15. Assevera Postigo que "Os processos judiciais tradicionais estiveram caracterizados por ser fundamentados de modo escrito e secreto através de expedientes ou pastas contendo todos os registros dos atos realizados durante o procedimento" (POSTIGO, Leonel González. Bases da reforma processual penal no Brasil: lições a partir da experiência na América Latina. In: COUTINHO, Jacinto Nelson de Miranda; COSTA DE PAULA, Leonardo; NUNES DA SILVEIRA, Marco Aurélio. Mentalidade inquisitória e 
Particularmente em relação a legislação brasileira, o Código de Processo Criminal de 1832 foi o primeiro código após a independência do Brasil e o diploma legal mais importante em reação às leis tiranas da monarquia portuguesa, tornando-se uma composição simbólica dos anseios do pensamento iluminista da época ${ }^{10}$. Segundo Pierangelli, esse código não teve fortes influências do Code Criminelle Napolêonico, uma vez que continha pensamentos iluministas da época em seu texto, o que o deixou muito mais liberal que o francês ${ }^{11}$. Porém, é importante notar que "o legislador de 1832 ficou no meio termo entre o procedimento acusatório, adotado na Inglaterra, e o procedimento misto, vigente na França”"12.

processo penal no Brasil. O sistema acusatório e a reforma do CPP no Brasil e na América Latina - vol. 3. Florianópolis: Empório do Direito, 2017, p. 17).

10 MARQUES, José Frederico. Tratado de direito processual penal. v. 1. São Paulo: Saraiva, 1980, p. 117. Segundo o autor, "Proclamada a independência e organizado constitucionalmente o País, passam a encontrar agasalho e consagração, no direito pátrio, todas as idéias liberais que vinham de substituir as iníquas práticas do sistema inquisitivo." (MARQUES, José Frederico. Tratado de direito processual penal. v. 1. São Paulo: Saraiva, 1980, p. 117).

11 PIERANGELLI, José Henrique. Processo penal: evolução histórica e fontes legislativas. Bauru: Jalovi, 1983, p. 92-93.

12 POLI, Camilin Marcie de. O Inquérito Policial e sua utilização na fase processual penal: (des)conformidade com o devido processo penal. 2015. $213 \mathrm{f}$. Dissertação (Mestrado em Direito) - Programa de Pós-Graduação em Direito, Setor de Ciências Jurídicas, Universidade Federal do Panará, Curitiba, 2015, p. 128. Importante salientar que o Código de Processo de 1832 se mostrou pouco eficiente para o governo imperial em relação à restauração da ordem e da tranquilidade e, por isso, algumas leis com caráter autoritário foram promulgadas, especialmente a Lei $n^{0} 261$, de 3 de dezembro de 1841 e seu Regulamento $n^{\circ} 120$, de 31 de janeiro de 1842, como instrumentos para o governo conter a desordem e impor a sua autoridade em toda a nação (MARQUES, José Frederico. Tratado de direito processual penal. v. 1. São Paulo: Saraiva, 1980, p. 118). Desse modo, ainda que se possa constatar uma certa evolução do Código Criminal imperial em relação as Ordenações Filipinas, nota-se que o problema era político e não jurídico - assim como na França pós revolução -, de maneira que esse código não teve tempo de se efetivar, pois prevaleceu as reformas legislativas que modificavam substancialmente a estrutura por ele trazida (POLI, Camilin Marcie de. O Inquérito Policial e sua utilização na fase processual penal: (des)conformidade com o devido processo penal. 2015. 213 f. Dissertação (Mestrado em Direito) - Programa de Pós-Graduação em Direito, Setor de Ciências Jurídicas, Universidade Federal do Panará, Curitiba, 2015, p. 133). 
Outra característica importante do Código Napoleônico que foi incorporado nos processos latino americanos, era que o sistema de valoração adotado era o da livre convicção. Isso fez com que os julgadores pudessem adotar qualquer elemento introduzido no processo para valorar na sua convicção, inclusive os atos praticados na fase pré-julgamento, que era escrita, secreta e sem contraditório. Assim, os interrogatórios do acusado e dos testemunhos anteriores a fase de debates que estavam documentados nos expedientes podiam ser utilizados na fase de debates orais para contradizer as versões dadas oralmente, bem como, apesar de não oficialmente, podiam ser utilizados na valoração da decisão final ${ }^{13}$.

Dessa forma, de nada adianta existir uma fase acusatória de debates se tem-se a possibilidade generalizada de utilização dos depoimentos e dos demais elementos produzidos na fase inquisitorial, fato que ainda ocorre frequentemente até os dias atuais no processo penal brasileiro ${ }^{14}$. Cordero explicando sobre esse modelo de duas fases afirma que

De la instrucción al debate "se pasa de la oscuridad a la luz plena”; allí se trataba de un labirinto oscuro y secreto por completo parcializado y rodeado por intereses represivos, como lo quería la Ordenanza criminal; acá "todo es publicidad, debates orales, libre defensa y plena discusión”. Inquisición y espectáculo acusatorio; pero, según lo hemos notado, se trata de una distribución aparente: los autos instructorios pesan sobre la decisión; [...] y no estando prohibido explicitamente leer las declaraciones de los testigos ausentes [...], parece inevitable um amplio uso de las lecturas ${ }^{15}$.

13 MAIER, Julio B. J. Derecho procesal penal. Tomo I: fundamentos. Buenos Aires: Del Puerto, 2006, p. 357-359.

14 Isso provém desde o Code d'Instruction Criminelle que diferente do código anterior a ele (Code des Délits et des Peines) não previu a regra de que era proibida a leitura aos jurados dos depoimentos de testemunhas não presentes na sala de julgamento e sem essa regra de proibição, os documentos escritos que foram produzidos na fase de investigação eram amplamente utilizados na fase de julgamento e incidiam na decisão (CORDERO, Franco. Guida alla procedura penale. Torino: UTET, 1986, p. 72-73).

15 CORDERO, Franco. Procedimiento Penal. Tomo I. Bogotá: Editorial Temis, 2000 , p. 58. 
Portanto, durante o século XIX e início do século XX, uma boa parte dos países latino-americanos, por influência da Europa continental, adotou um modelo de processo penal próximo a essas linhas ${ }^{16}$. Assim, em grande parte do século XX o sistema inquisitorial estava vivo e potente, ainda que revestido de diversas roupagens: alguns países conservavam diretamente o velho modelo espanhol totalmente escrito, secreto, com o sistema de provas legais e identidade entre o acusador e o julgador (Chile, Paraguai, Venezuela, Uruguai, Nicaragua, Honduras, Guatemala e Argentina em seu sistema federal e em alguns estados); já outros países adotaram durante o século XX as formas do Código francês, seja diretamente ou por influência da Itália, que não deixa de ser também um sistema escrito e inquisitório (Bolívia, Equador, Peru, El Salvador, República Dominicana, Haiti e Brasil) ${ }^{17}$.

Dessa forma, essa organização conforme os fins de uma afirmação de um poder central e do controle populacional, cria uma "tradição inquisitorial"18 característica dos processos criminais latino-americanos, no qual os procedimentos em quase sua totalidade é uma investigação escrita e secreta conforme as necessidades do poder estatal e de seu êxito ${ }^{19}$.

Essa tradição inquisitorial cria uma cultura inquisitória típica dos países latino-americanos, que mesmo influenciados por algumas ideias

16 LANGER, Máximo. Revolução no processo penal latino-americano: difusão de ideias jurídicas a partir da periferia. Revista da Faculdade de Direito da UFRGS, n. 37, p. 4-51, 2017, dez., p. 16.

17 BINDER, Alberto M. La fuerza de la Inquisición y la debilidad de la República. Política Criminal Bonaerense, n. 1, 2003, p. 7.

18 Segundo Binder: "Lo que llamamos 'tradición inquisitorial' es el conjunto de factores que condicionan fuertemente la actuación de esos actores. Estos factores son tanto prácticas internas como externas que finalmente constituyen la estructura del campo como la subjetividad de los actores, en una relación que no se puede explicar bajo la lógica de lo interno o la externo, lo objetivo y lo subjetivo. No es un problema de un escenario ya estructurado donde los actores actúan com cierta 'mentalidad', sino uma imbricación mucho más compleja de prácticas, unidad inescindible de 'objetividades' y 'subjetividades' (BINDER, Alberto M. La fuerza de la Inquisición y la debilidad de la República. Política Criminal Bonaerense, n. 1, 2003, p. 9-10).

19 MAIER, Julio B. J. Situación de la justicia penal y problemas de los sistemas escritos. Revista de la Asociación de Ciencias Penales de Costa Rica, junio 1991, $\mathrm{n}^{\mathrm{o}} 4$, p. 3 . 
republicanas, mantiveram suas características principais: (a) procedimento escrito e secreto no qual o mais importante é o que está documentado (quod non est in acta no est in mundo); (b) uma administração da justiça secreta, ainda que existam algumas normas que estabeleçam a publicidade de alguma parte do processo; (c) um procedimento com pouco respeito ao imputado, já que ele não é sujeito, mas objeto sobre o qual recai a investigação; (d) a desnaturalização da fase de juízo como tal, já que na medida em que o procedimento se converte em dossiês ou expedientes, a parte mais importante é a fase pré-judicial; (e) a delegação das funções judiciais para empregados subalternos, já que a formalização excessiva e a burocratização do trabalho produzem uma sobrecarga de trabalho que impede que o juiz possa atender todos os $\operatorname{casos}^{20}$.

A cultura inquisitória calcada nessas características e permanecente no famigerado sistema misto coloca um peso muito intenso na fase preliminar, que acaba sendo a principal fase na formação da prova penal, apesar de toda a limitação da defesa e do consequente contraditório, além da tensão existente entre os anseios punitivos dos órgãos de investigação e dos direitos fundamentais do imputado. Essas questões serão tratadas com maior profundidade no processo penal brasileiro nos itens a seguir.

\section{PROBLEMA DA EXPANSÃo DA INVESTIGAÇÃo PRELIMINAR E A FALÁCIA DO SISTEMA BIFÁSICO: A CONSTRUÇÃO DO SUJEITO CRIMINOSO PELAS POLÍCIAS BRASILEIRAS}

A doutrina e a prática processual penal notam que a investigação preliminar é a fase principal na persecução penal brasileira até os dias atuais, uma vez que é nela que são produzidas as provas principais que irão formar a convicção do julgador ao final do processo, dado que com o que foi visto no tópico anterior criou-se uma cultura inquisitória que fez com que o sistema processual penal brasileiro fosse ressignificando seus conceitos para se readaptar a cada momento histórico de forma que mantivesse de alguma forma seu núcleo inquisitivo, o que se pode chamar de um sistema neoinquisitório.

20 BINDER, Alberto M. La justicia penal en la transición a la democracia en américa latina. Alicante: Biblioteca Virtual Miguel de Cervantes, 2005, p. 85. 
Com isso, o sistema processual penal conseguiu manter até o momento atual a ideia de duas fases, no qual a primeira seria uma fase administrativa e formada por hipóteses acusatórias. Todavia, é nessa fase também onde as maiores arbitrariedades ocorrem e a defesa tem seu papel limitado, o que acarreta uma maior acumulação de poderes ou forças processuais à acusação $0^{21}$ e possibilita uma maior incidência de manipulações processuais.

Esse sistema bifásico inspirado no Code d'Instruction Criminelle de Napoleão, com uma fase pré-processual inquisitória e uma fase processual (teoricamente) acusatória, cria o chamado por Cordero de "monstro de duas cabeças”, pois as provas são colhidas na inquisição do inquérito, sem a participação efetiva da defesa e sem o consequente contraditório e depois são levadas para dentro do processo por meio de um malabarismo discursivo que imunize a decisão ${ }^{22}$.

No Brasil, a herança de uma forte cultura inquisitória coloca a investigação como o centro da produção probatória, o que faz com que o Ministério Público pouco acrescente em juízo ao que foi produzido no inquérito, fazendo com que apenas haja uma ratificação judicial (ilegal) e transformando o processo em apêndice da investigação ${ }^{23}$.

Em relação à particular história dessa peça de investigação no Brasil, qual seja o inquérito, é importante traçar algumas considerações.

${ }^{21}$ Trata-se do que Schünemann chama de "aglomeração quântica de poder" (SCHUnemanN, Bernd. La Reforma del Proceso Penal. Madrid: Dykinson, 2005, p. 35). No mesmo sentido que Foucault utiliza para falar do saber acusatório dos processos na Idade Média em Vigiar e Punir, o inquérito policial brasileiro continua sendo uma forma de saber privilegiado da acusação (FOUCAULT, Michel. Vigiar e Punir: história da violência nas prisões. $38^{a}$ ed. Rio de Janeiro: Vozes, 2010).

${ }^{22}$ LOPES JR., Aury Lopes. Fundamentos do processo penal: Introdução crítica. $2^{\mathrm{a}}$ ed. São Paulo: Saraiva, 2016, p. 161-162.

${ }^{23}$ CHOUKR, Fauzi Hassan. Inquérito policial: novas tendências e práticas. Boletim IBCCRIM, São Paulo, v. 84, novembro, 1999. Segundo Giacomolli “a frágil regulamentação da metodologia da busca de informações na fase preliminar do processo penal, aliada à utilização de métodos, meios e fontes próprios da fase judicial aumenta a valoração probante dessa etapa (derivação à história inquisitorial) no julgamento." (GIACOMOLLI, Nereu José. A fase preliminar do processo pena. Crises, misérias e novas metodologias investigatórias. Rio de Janeiro: Lumen Juris, 2011, p.12). 
No período do Império, até o primeiro Código de Processo Penal em 1832, cabia aos juízes de paz lavrar o auto de corpo de delito e formar a culpa dos delinquentes (chamado de sumário de culpa). Essa formação de culpa incluía a inquirição de testemunhas, mas também o direito do acusado de contestá-las. Essas funções duraram até 1841, quando uma nova lei passou a atribuir aos chefes de polícia e a seus delegados e subdelegados, em conjunto com juízes municipais, a preparação e a formação do sumário de culpa ${ }^{24}$. Em 1871, por advento da Lei 2.033, a formação da culpa passou a ser atribuição exclusiva de juízes de direito e municipais, cabendo à polícia apenas proceder ao inquérito policial, que consistia em "todas as diligências necessárias para o descobrimento dos fatos criminosos, de suas circunstâncias e dos autores e cúmplices, deve ser reduzido à instrumento escrito" 25 .

Tem-se que a partir do Código de 1941 o inquérito passa a assumir a função antes exercida pelo sumário de culpa. Nele, o juiz recebe a denúncia sustentada sem qualquer oportunidade da defesa se manifestar

24 A Lei de 3 de dezembro de 1841 procurou criar um aparelhamento policial altamente centralizado e armar o Governo de poderes suficientes para levar a bom termo a tarefa que se propunha, de tornar efetiva a autoridade legal. Para isso, à autoridade policial cabia além das funções de polícia administrativa e de polícia judiciária, funções judicantes, como a formação da culpa, a concessão de mandados de busca, o julgamento de crimes de sua alçada etc. Assim, operou-se uma junção entre a polícia e a justiça, passando de um judiciarismo policial para um policialismo judiciário, o que fez com que esse policialismo se tornasse fonte de arbitrariedade, pois a justiça policial ficava a mercê da política para perseguir os adversários e proteger os seus aliados (MARQUES, José Frederico. Tratado de direito processual penal. v. 1. São Paulo: Saraiva, 1980, p. 119-120).

MISSE, Michel. O inquérito policial no Brasil. DILEMAS: Revista de Estudos de Conflito e Controle Social - Vol. 3 - no 7 - jan./fev./mar., p. 35-50, 2010, p. 37-38. Segundo Poli: "Com o advento da Lei no 2.033, de 20 de setembro de e do Decreto $\mathrm{n}^{\circ} 4.824$, de 22 de novembro de iniciou-se uma nova fase na história do processo penal brasileiro, uma vez que a estrutura até então vigente foi alterada. A principal mudança foi a separação da polícia e da justiça, o que ofuscou, de certa forma, o policialismo reacionário criado pela Lei de 03 de dezembro de 1941", e desse modo "a polícia passou a estar ligada ao Poder Executivo, não mais fazendo funções judicantes, uma vez que se optou pelo inquérito policial, ao invés do juizado de instrução." (POLI, Camilin Marcie de. O Inquérito Policial e sua utilização na fase processual penal: (des)conformidade com o devido processo penal. 213 f. Dissertação (Mestrado em Direito) - Programa de Pós-Graduação em Direito, Setor de Ciências Jurídicas, Universidade Federal do Panará, Curitiba, 2015, p. 136-138). 
previamente e, ainda mais grave, possibilita-se a condenação como base nos elementos nele colhidos ${ }^{26}$.

Importante afirmar que o inquérito é espécie do gênero investigação, já que existem outros modelos oficiais de investigação ${ }^{27}$, bem como outros órgãos encarregados da instrução preliminar ${ }^{28}$, e que a opção legislativa pelo modelo de investigação policial é basicamente fundamentada na extensão territorial brasileira. É o que traz a própria Exposição de Motivos ao Código de Processo Penal de 1941 - ainda que se incline bastante ao modelo de juizado de instrução.

Desse modo, partindo de um diagnóstico do ponto de vista empírico do inquérito policial, mais especificamente em um estudo de âmbito nacional sobre o inquérito policial coordenado pelo sociólogo Michel Misse, a law in action mostra uma ambivalência entre a legislação e a tradição, assim como as alterações introduzidas nos últimos anos nessa área, localizam solução nas práticas abraçadas. E o quanto essas mudanças atravessam o perímetro de "uma legalidade já por si considerada antiquada, inquisitorial, quando não autoritária, em direção a uma ilegalidade prática, sob a forma de uma 'lógica em uso' justificada pela eficiência", o que faz com que haja uma "informalidade eficiente" que, no entanto, "diminui tanto as garantias dos acusados quanto não foi capaz de aumentar a capacidade investigativa da Polícia"29.

26 SCARANCE FERNANDES, Antonio. Teoria Geral do Procedimento e O Procedimento no Processo Penal. São Paulo: Editora Revista dos Tribunais, 2005, p. 97-98. Apesar de na redação original do Código de Processo Penal de 1941 não existir expressamente essa possibilidade de condenação com base no inquérito, a doutrina e a jurisprudência admitiam e tinham como uma vertente (CHOUKR, Fauzi Hassan. Garantias constitucionais na investigação criminal. Rio de Janeiro: Lumen Juris, 2006, p. 118-124).

27 Entre as formas de instrução preliminar estão o inquérito policial, comissões parlamentares de inquérito (CPI), procedimento de investigação criminal (PIC), sindicâncias etc.

28 Além do sistema oficial de investigação preliminar com a Polícia Judiciária como titular (sistema policial), existe o sistema do Juiz Instrutor (sistema judicial) e do Promotor Investigador. Cf. LOPES JR., Aury; GLOECKNER, Ricardo Jacobsen. Investigação preliminar no processo penal. São Paulo: Saraiva, 2013, p. 127-169.

29 MISSE, Michel. O inquérito policial no Brasil. DILEMAS: Revista de Estudos de Conflito e Controle Social - Vol. 3 - no 7 - jan./fev./mar., p. 35-50, 2010, p. 39. 
Afora isso, tem-se no Brasil uma peculiar formação nas polícias, dividindo-se as funções investigativas e ostensivas entre as chamadas Polícia Civil e Polícia Militar ${ }^{30}$, o que expõe o ranço autoritário permanecente do período de ditadura militar no Brasil. Essa militarização das funções do policiamento ostensivo que põe a Polícia Militar como força auxiliar e de reserva do Exército ilustra a herança mantida dos tempos ditatoriais. Por outro lado, não se pode esquecer das práticas não menos autoritárias, porém mais subterrâneas, da Polícia Civil na busca incessante da "verdade" da infração penal ${ }^{31}$.

Embora essa violência institucional já existisse antes do início da ditadura, foi nesse período que ela se desenvolveu e se mostrou mais atroz e letal. Contudo, mesmo após o período de redemocratização e a formalização constitucional de garantias fundamentais contra atos arbitrários do Estado, não foi o suficiente para o abandono de práticas autoritárias no âmbito da segurança pública, especialmente em relação ao problema da violência policial ${ }^{32}$.

Justamente esse o ponto onde a práxis policial encontra-se com esse dispositivo inquisitorial (inquérito policial), funcionando como um legitimador do regime de verdade atuado pela polícia: "Sua zona periférica é constituída pela intersecção do ethos policial com os discursos e práticas investigativas; longe de ser constrangida pela legislação que rege a matéria investigativa, estabelece uma estratégia de gestão de ilegalidades, a qual envolve a tradução da 'verdade' extraída até mesmo pelo uso direto da força - diante da prática de torturas, ainda que em manifestações mais sutis - para um discurso oficial assepticamente 'imparcial' (inclusive assinado por duas testemunhas 'convidadas')” (SAMPAIO, André Rocha. Profanando o dispositivo "inquérito policial" e seu ritual de produção de verdades. $R e$ vista Brasileira de Ciências Criminais, vol. 134, p. 351-383, 2017, p. 364).

30 A Constituição brasileira em seu artigo 144 . $\S 4^{\circ}$ e $5^{\circ}$ respectivamente assevera que: "Às polícias civis, dirigidas por delegados de polícia de carreira, incumbem, ressalvada a competência da União, as funções de polícia judiciária e a apuração de infrações penais, exceto as militares."

"Às polícias militares cabem a polícia ostensiva e a preservação da ordem pública; aos corpos de bombeiros militares, além das atribuições definidas em lei, incumbe a execução de atividades de defesa civil."

31 AMARAL, Augusto Jobim do. A ostensividade da soberania policial. In: GLOECKNER, R. J.; FRANÇA, L. A.; RIGON, B. S (Orgs.). Biopolíticas: Estudos sobre política, governamentalidade e violência. Curitiba: iEA Academia, 2015, p. 303.

32 GLOECKNER, Ricardo Jacobsen; GONÇALVES, Paula Garcia. Letalidade policial e Ministério Público: das práticas de extermínio ao discurso legitimador. 
Além disso, a própria Constituição que descentralizou poderes e estipulou diversos benefícios sociais, não modificou as cláusulas relacionadas com as Forças Armadas, as Polícias Militares, o sistema judiciário militar e de segurança pública, permanecendo igual à Constituição de 1967 e sua emenda em 1969. Ademais, o fato das forças policiais serem auxiliares do Exército - como diz o art. $144, \S 6^{\circ}$ da Constituição - é algo comum em períodos de guerra ou de regimes autoritários ${ }^{33}$.

Revista Brasileira de Ciências Criminais, v. 130, p. 177-200, São Paulo: RT, abr., 2017, p. 200.

33 ZAVERUCHA, Jorge. Relações civil-militares: o legado autoritário da Constituição brasileira de 1988. In: TELES, Edson; SAFATLE, Vladimir (Org.). O que resta da ditadura: a exceção brasileira. São Paulo: Boitempo, 2010, p. 45-52. Cerqueira ao analisar os aspectos brasileiros afirma: "vê-se que o art. 144 da CF/88 (LGL \1988\3), é um capítulo destinado à segurança pública; nele são definidas as atribuições e a natureza jurídica organizacional das polícias e dos corpos de bombeiros militares. Essas organizações são consideradas forças auxiliares e reserva do Exército com atribuições, respectivamente, de polícia ostensiva e preservação da ordem pública e de execução de atividades de defesa civil. Temos organizações militares com missões de polícia e de defesa civil, ao lado de outras organizações policiais, de natureza civil. No capítulo que trata do papel das Forças Armadas, art. 142 da CF/88 (LGL \1988\3), são definidas suas missões: defesa da Pátria e a garantia dos poderes constitucionais e, por iniciativa de qualquer um deles, a garantia da lei e da ordem. Temos, portanto, os militares com atribuições no campo da segurança pública. [...] A grande diferença que se observa ao comparar a situação brasileira com a francesa, a portuguesa e a italiana, que também possuem polícias militares é, primeiro, o nível, já examinado, de inferioridade e de subordinação das Polícias Militares brasileiras em relação às forças Armadas; segundo, o fato do argumento da "terceira força", naqueles países, significar a exclusão de fato dos militares das questões da ordem interna, que acaba não ocorrendo na situação brasileira, isso porque a nossa Constituição permite ainda aos militares brasileiros uma forte presença na área da segurança pública e política.” (CERQUEIRA, Carlos Magno Nazareth. Questões preliminares para a discussão de uma proposta de diretrizes constitucionais sobre a segurança pública. Revista Brasileira de Ciências Criminais, v. 22, p. 139181, São Paulo: RT, abr./jun., 1998, p. 140-148). Segundo Zaverucha, "nossos constituintes não conseguiram se desprender do regime autoritário recém-findo e terminaram por constitucionalizar a atuação de organizações militares em atividades de polícia (Polícia Militar) e defesa civil (Corpo de Bombeiros), ao lado das polícias civis. As polícias continuaram constitucionalmente, mesmo em menor grau, a defender mais o Estado que o cidadão." (ZAVERUCHA, Jorge. Relações civil-militares: o legado autoritário da Constituição brasileira de 1988. In: TELES, Edson; SAFATLE, Vladimir (Org.). O que resta da ditadura: a exceção brasileira. São Paulo: Boitempo, 2010, p. 55). 
Segundo Pinheiro, os governos de transição trataram as instituições de segurança pública como instituições neutras capazes de se moldar a regimes autoritários ou democráticos, desconsiderando que as relações que compõe o Estado são vinculadas a sua estrutura, ou seja, subestimando o legado autoritário em suas práticas ${ }^{34}$.

Inclusive, nesse período de transição não houve qualquer discussão jurídica ou movimento político para que os atores do regime anterior fossem modificados, pelo contrário, permaneceram os potencialmente perpetradores da violência em todos os campos jurídicos nacionais, o que se denomina de "legado silencioso" 35 .

Esse legado pode ser identificado por uma estrutura administrativa que foi estruturada durante a ditadura militar (sobretudo por meio do Decreto Lei $n^{\circ}$ 200/67) e que permanece até os dias atuais de forma juridicamente justificada. Nesse sentido, conforme Bercovici, uma Constituição verdadeiramente democrática deveria obrigar a reformulação mesmo que parcial de todas as categorias tradicionais do direito administrativo, já que não adianta mudar a Constituição e permanecerem as mesmas regras administrativas autoritárias que regem as práticas do cotidiano, ao lado dos mesmos atores e com suas mentalidades ainda fincadas no regime antigo ${ }^{36}$.

Desse modo, a política de segurança pública no Brasil continua sendo a mesma praticada durante o período de ditadura com a mesma violência explícita e ilegal, bem como o combate ao crime corriqueiro segue seguindo as linhas convencionais anteriores a ditadura e que foram

34 PINHEIRO, Paulo Sérgio. Autoritarismo e transição. Revista USP, mar.-abr. -maio 1991, p. 50.

35 CHOUKR, Fauzi Hassan. Transição e consolidação da democracia: instrumentos, práticas e limitações na experiência brasileira. Florianópolis: Empório do Direito, 2016, p. 98.

36 BERCOVICI, Gilberto. "O direito constitucional passa, o direito administrativo permanece”: a persistência do direito administrativo de 1967. In: TELES, Edson; SAFATLE, Vladimir (Org.). O que resta da ditadura: a exceção brasileira. São Paulo: Boitempo, 2010, p. 78-79. Interessante observar que no âmbito do Poder Judiciário duas das principais leis administrativas de organização interna foram feitas na época da ditadura e permanecem até hoje: Lei Complementar $n^{\circ} 35$, de 14 de março de 1979, mais conhecida como Lei Orgânica da Magistratura Nacional (LOMAN) e Lei n ${ }^{\circ}$ 5.510, de 30 de maio de 1966, que organiza a Justiça Federal de primeira instância. 
enriquecidas durante esse período, tal qual a militarização do policiamento ostensivo, que foi consagrado pela Constituição de 1988 e conserva grande apoio no interior da sociedade ${ }^{37}$.

Outro problema referente às instituições policiais tem relação com o controle interno e externo da atividade policial. No que tange ao controle interno, o órgão responsável são as Corregedorias de Polícia, contudo "sofrem as implicações do corporativismo - considerando que os corregedores são, também, policiais, e, neste ponto, se encontra grande resistência em punir um colega" ${ }^{38}$.

Já em relação ao controle externo, o Brasil adotou o esquema de Ouvidoria de Polícia, que embora sejam órgãos de fiscalização externa, apenas tem a função do recebimento das reclamações, sem possuir uma performance mais ativa na fiscalização dos atos policiais. Porém, após a constituição de 1988 o Ministério Público passou a ter um papel de destaque no controle externo da atividade policial, podendo-se afirmar que é ele o encarregado constitucional desta função.

No entanto, na prática essa atribuição não é cumprida de forma adequada por esse órgão se comparada com as demais funções exercidas pelo Ministério Público previstas na Constituição ${ }^{39}$. Dessa forma, com

37 PINHEIRO, Paulo Sérgio. Autoritarismo e transição. Revista USP, mar.-abr. -maio 1991, p. 51-52. Conforme Oliveira, no Brasil existem classes de pessoas "torturáveis" e "não torturáveis" pela polícia: "Em países como o Brasil, boa parte da opinião pública - o que inclui os próprios 'torturáveis' - convive pacificamente com a ideia de que a polícia pode prender e bater em delinquentes. [...] Potencialmente ‘torturáveis' e ‘elimináveis', e, portanto, teoricamente os mais interessados numa polícia respeitadora dos direitos humanos, os segmentos mais pobres, entretanto, são os mais sensíveis aos discursos truculentos presentes na mídia." (OLIVEIRA, Luciano. Do nunca mais ao eterno retorno: uma reflexão sobre a tortura. $2^{\mathrm{a}}$ ed. São Paulo: Editora Brasiliense, 2009, p. 28-31).

38 GLOECKNER, Ricardo Jacobsen; GONÇALVES, Paula Garcia. Letalidade policial e Ministério Público: das práticas de extermínio ao discurso legitimador. Revista Brasileira de Ciências Criminais, v. 130, p. 177-200, São Paulo: RT, abr., 2017, p. 180.

39 Nesse sentido, especialmente no tocante à omissão do Ministério Público em relação às políticas de segurança pública cf. ÁVILA, Thiago André Pierobom de. O controle pelo ministério público das Políticas de segurança pública. In: Conselho Nacional do Ministério Público. O Ministério Público e o controle externo da Atividade Policial: Dados 2016. Brasília: CNMP, 2017. 
todas essas deficiências apresentadas tanto no controle interno como no externo da polícia brasileira, ela acaba por ter uma atuação extremamente discricionária ${ }^{40}$ e seus atos são muitas vezes legitimados por discursos retóricos que contribuem para que a polícia continue com uma atuação violenta, letal e seletiva ${ }^{41}$.

Esse discurso legitimador da violência policial no Brasil passa por aspectos de uma política criminal caldada no combate ao inimigo interno que acaba sendo interiorizada pela instituição policial e refletindo em suas práticas. Como afirma Foucault ${ }^{42}$, a política não passa da continuação da guerra por outros meios. Desta forma, Gloeckner e Gonçalves apresentam duas questões quanto a política criminal, especialmente a brasileira: (a) não deixa, em momento algum, de possuir o caráter de espécie de "política”, assumindo assim conotações de guerra estendida e contínua, o que explica o elevado índice de letalidade policial legitimado

40 Essa discricionariedade ainda é mais extensa se verificarmos as expressões que o CPP utilizou no tocante à investigação criminal. Nesse sentido, Sampaio: "Uma breve análise do Título II do nosso CPP em vigor expõe um aspecto sintomático; apesar de se tratar de um título curto (apenas 18 artigos para regular toda a investigação criminal), ele apela para expressões do tipo 'no que for aplicável', 'se possível', 'interesse da sociedade' e 'ordem pública'. Em suma, regula pouco e o faz de modo 'aberto', com normas de alto poder denotativo, dando margem a uma ampla discricionariedade policial." (SAMPAIO, André Rocha. Um dispositivo chamado "Inquérito Policial". Boletim Informativo IBRASPP - Ano 03, $\mathrm{n}^{\circ}$ 05, p. 39-41, 2013, p. 40).

GLOECKNER, Ricardo Jacobsen; GONÇALVES, Paula Garcia. Letalidade policial e Ministério Público: das práticas de extermínio ao discurso legitimador. Revista Brasileira de Ciências Criminais, v. 130, p. 177-200, São Paulo: RT, abr., 2017, p. 180-181. Nesse sentido existem várias pesquisas sobre a letalidade e a brutalidade das polícias brasileiras, bem como a naturalização e a conveniência com esses. Cf. LEMGRUBER, Julita; MUSUMECI, Leonarda; CANO, Ignacio. Quem vigia os vigias? - um estudo sobre controle externo da polícia no Brasil. Rio de Janeiro: Record, 2003; MISSE, Michel; GRILLO, Carolina Christoph; TEIXEIRA, César Pinheiro; NERI, Natasha Elbas. Quando a polícia mata: homicídios por "autos de resistência" no Rio de Janeiro (2001-2011). Rio de Janeiro: NECVU; BOOKLINK, 2013; ANISTIA INTERNACIONAL. Você matou meu filho!: homicídios cometidos pela polícia militar na cidade do Rio de Janeiro. Rio de Janeiro: Anistia Internacional, 2015; D’ELIA FILHO, Orlando Zaccone. Indignos de vida: a forma jurídica da política de extermínio de inimigos na cidade do Rio de Janeiro. Rio de Janeiro: Revan, 2015.

FOUCAULT, Michel. Em Defesa da Sociedade. São Paulo: Martins Fontes, 2010, p. 15. 
pelas instâncias burocráticas elitizadas: Ministério Público e, Judiciário; (b) como modalidade de política, ela é articulada por um discurso que opera em dois níveis: o primeiro destes níveis, coincide com as técnicas de neutralização ${ }^{43}$ isto é, as racionalizações para o descumprimento de normas; o segundo está na política criminal como uma tecnologia de combate instrumentalizada a partir dos dispositivos de soberania incorporados ao saber jurídico e possuindo enraizamento em relações de força estabelecida em determinado momento na e pela guerra ${ }^{44}$.

Desse modo, tem-se que a polícia realiza o trabalho soberano obsceno conduzido pela política, criando, à seu modo, zonas de indiferenciação onde todos somos excluídos e capturados da exceção soberana para além da coação respaldada juridicamente, em que o espaço público democrático é tornado um disfarce da decisão policial, colocando em evidência a soberania da polícia, uma vez que o poder soberano é aquele que preserva o direito de agir e de se impor soberanamente até mesmo sobre a morte dos cidadãos, definindo quem se encaixa ou não no conceito de "vida nua". Assim, pode-se dizer juntamente com Amaral que "é no movediço terreno da contiguidade entre violência e direito que a polícia se apresenta” ${ }^{45}$.

43 Cf. SYKES, Gresham M.; MATZA, David. Techniques of Neutralization: A Theory of Delinquency. American Sociological Review, Vol. 22, No. 6, p. 664670, Dec., 1957, especialmente no tocante as técnicas de "negação da ilicitude" e "negação de condição da vítima" em relação aos atos ilegais praticados pelos policiais que são arquivados e justificados pelos membros do Ministério Público e do Judiciário como uma forma de consentir com os discursos policiais, especialmente no que tange aos chamados "autos de resistência" (vale ressaltar que a Resolução Conjunta ${ }^{\circ} 2$, de 13 de outubro de 2015, do Conselho Superior de Polícia e do Conselho Nacional dos Chefes da Polícia Civil proibiu esse termo que foi substituído por "lesão corporal decorrente de oposição à intervenção policial" ou "homicídio decorrente de oposição à intervenção policial", o que na prática não mudou muita coisa).

44 GLOECKNER, Ricardo Jacobsen; GONÇALVES, Paula Garcia. Letalidade policial e Ministério Público: das práticas de extermínio ao discurso legitimador. Revista Brasileira de Ciências Criminais, v. 130, p. 177-200, São Paulo: RT, abr., 2017, p. 186.

45 AMARAL, Augusto Jobim do. "Mal de Polícia” - À propósito de uma criminologia radical. Revista Brasileira de Ciências Criminais, v. 111, p. 263-291, São Paulo: RT, nov./dez., 2014, p. 272-273. 
Isso é verificado no Brasil com o extermínio de pessoas pobres em áreas consideradas miseráveis da cidade (favelas e periferias) por meio de uma atividade de governo, que atua através de uma tecnologia totalmente diversa da jurídica:

O dispositivo da segurança pública, mais do que atuar sobre atos delitivos, recai sobre a gestão do perigo. A tecnologia da segurança tem por função higienizar o corpo social de fatores de risco (de regra associados, na política de extermínio, à figura do traficante de drogas). Por isso é que a sua atuação se dá muito mais como norma do que como regra. A norma e seu efeito - a normalização se aplica tanto a um corpo disciplinar quanto a uma população, voltada a partir de aspectos de regulação ${ }^{46}$.

Essa gestão do risco é operacionalizada basicamente pela polícia por meio de estratégias que tem como finalidade o controle populacional através da "gestão dos ilegalismos", colocando as ilegalidades como um perigo permanente que deve ser exposta de modo sensacionalista de maneira que determinadas classes de criminosos traga medo generalizado ${ }^{47}$.

Nessa senda, o inquérito policial ${ }^{48}$ apresenta-se com um papel que vai além do de apurar crimes, possuindo uma função estratégica que ao mesmo tempo é mais ampla e mais sutil com o azo do "bom funcionamento" do aparelho penal e dos aparelhos governamentais ${ }^{49}$. Além disso, o sistema de investigação brasileiro foi construído em uma política-criminal cuja constante histórica tem sido a ilusória gestão pelo

46 GLOECKNER, Ricardo Jacobsen; GONÇALVES, Paula Garcia. Letalidade policial e Ministério Público: das práticas de extermínio ao discurso legitimador. Revista Brasileira de Ciências Criminais, v. 130, p. 177-200, São Paulo: RT, abr., 2017, p. 186.

47 AMARAL, Augusto Jobim do e ROSA, Alexandre Morais da. Cultura da Punição: a ostentação do horror. ed. 3. Florianópolis: Empório do Direito, 2017, p. 27.

48 Apesar da divisão no Brasil entre Polícia Militar e Polícia Civil, sendo a última quem pode investigar por meio do instituto do inquérito policial, a Polícia Militar tem um papel importante no inquérito pois em muitos casos ela quem prende em flagrante e leva o fato para conhecimento da autoridade policial, além de em diversos casos serem testemunhas de acusação.

49 SAMPAIO, André Rocha. Um dispositivo chamado "Inquérito Policial”. Boletim Informativo IBRASPP - Ano 03, nº 05, p. 39-41, 2013, p. 40. 
medo. Como assinalam Figueiredo Dias e Costa Andrade ${ }^{50}$, a subcultura policial tem seus próprios modelos pré-concebidos de estereótipo de criminosos potenciais e prováveis, agindo por um ethos característico da própria instituição policial ${ }^{51}$, fazendo com que o tratamento seja diferenciado conforme ele se encaixe ou não no perfil pré-fixado, ou seja, a polícia frente a um indivíduo com "perfil de autor ideal" de um delito, tende a atuar com excessivo rigor podendo, até mesmo, agir ilicitamente para alcançar todos os meios de incriminação, cometendo, inclusive, as maiores barbáries ${ }^{52}$.

Isso fica mais sério quando o instituto do inquérito policial acaba sendo, por sua natureza, um primeiro juízo do Estado acerca do fato criminoso, haja vista que a versão nele exposta tende a ser nele reproduzida durante a persecução penal, desde a denúncia do Ministério Público, até o momento da formação da prova e convicção do juiz ${ }^{53}$. Nesse ponto,

50 FIGUEIREDO DIAS, Jorge; COSTA ANDRADE, Manuel. Criminologia - O Homem Delinquente e a Sociedade Criminógena. Coimbra, 1992, p. 443.

51 FERRAJOLI, Luigi. Direito e Razão: teoria do garantismo penal. Revista dos Tribunais, 2002, p. 704-711.

52 Nesse sentido, Misse afirma que a demanda social por punição pode levar à incriminação preventiva. Essa demanda faz com que a expectativa por uma punição tende a assimilar o crime ao sujeito, ao passo que a periculosidade do indivíduo passa a ser entendida por traços que ele apresente: "A seleção desses traços, como no processo de estigmatização interliga causalmente variáveis de pobreza urbana, baixa escolaridade e preconceitos de cor e marca ao que se espera que seja uma 'carreira criminosa'”. Nesse ponto, a “sujeição criminal antecipa-se à busca de evidencias empíricas no processo de construção da verdade 'real' (eis o eufemismo através do qual a polícia distingue a 'sua' verdade da 'verdade' judicial). Para poupar tempo e esforços, basta "apertar" suspeitos e testemunhas para obter a verdade, isto é, a versão dos fatos. Uma vez que essa é a estratégia, então a tomada de depoimentos por escrito, com fé pública, em cartório, na delegacia, toma a forma de uma instrução criminal preliminar, sem contraditório, cujo nome é 'inquérito policial'” (MISSE, Michel. O Papel do Inquérito Policial no Processo de Incriminação no Brasil: algumas reflexões a partir de uma pesquisa. Revista Sociedade e Estado - Vol. 26, n.1, Jan./Abr. 2011, p. 17-19).

53 GHIRINGHELLI DE AZEVEDO, Rodrigo; VASCONCELLOS, Fernanda Bestetti. O Inquérito Policial em Questão - Situação atual e a percepção dos Delegados de Polícia sobre as fragilidades do modelo brasileiro de investigação criminal. Revista Sociedade e Estado - Volume 26 Número 1 Janeiro/Abril, 2011, p. 63. Para Misse: "O inquérito policial é a peça mais importante do processo de incriminação no Brasil. É ele que interliga o conjunto do sistema, 
Giacomolli assevera que é a valoração atribuída à fase pré-processual no decorrer da fase de debates em contraditório que determinará se um processo é democrático e constitucionalmente adequado ou se é somente um simulacro de processo ${ }^{54}$.

\section{A BURLA INTERNA NO PROCESSO PENAL BRASILEIRO EM DESFAVOR DO CONTRADITÓRIO: A BRECHA NO ARTIGO 155 E O "JOGO SUJO" PROCESSUAL}

Conjuntamente com o exposto no tópico anterior, pode-se considerar praticamente pacificado na doutrina processual penal que o inquérito policial é um sistema falido que não cumpre com sua função principal de esclarecer com grau de probabilidade a notícia-crime para fundamentar o processo e que, portanto, os atos praticados durante ele, apesar de serem importantes para o início ou não da ação penal, não devem servir como juízo de certeza na hora de valorar a condenação ou absolvição do acusado na sentença. Essa ineficácia do inquérito faz com

desde o indiciamento de suspeitos até o julgamento. A sua onipresença no processo de incriminação, antes de ser objeto de louvação, é o núcleo mais renitente e problemático de resistência à modernização do sistema de justiça brasileiro. Por isso mesmo, o inquérito policial transformou-se, também, numa peça insubstituível, a chave que abre todas as portas do processo e que poupa trabalho aos demais operadores do processo de incriminação - os promotores e juízes" (MISSE, Michel. O Papel do Inquérito Policial no Processo de Incriminação no Brasil: algumas reflexões a partir de uma pesquisa. Revista Sociedade e Estado - Vol. 26, n.1, Jan./Abr. 2011, p. 19). Por outro lado, pode-se concluir que "Essa esquizofrenia por que passa a investigação criminal brasileira, levada às últimas consequências, longe de prejudicar o exercício do poder, contribui para seu aspecto disciplinar: [...], por estar submetida a um regime de direito administrativo, seus atos possuem o 'atributo da presunção da legitimidade', ou seja, inverte a polaridade da carga probatória para a defesa, ferindo de morte a presunção de inocência e preenchendo expectativas (fundadas eventualmente em presunções) que são então normalizadas, nesse processo de (re)construção de verdade ameaçado pela contaminação da evidência" (SAMPAIO, André Rocha. Profanando o dispositivo "inquérito policial" e seu ritual de produção de verdades. Revista Brasileira de Ciências Criminais, vol. 134, p. 351-383, 2017, p. 362).

GIACOMOLLI, Nereu José. A fase preliminar do processo pena. Crises, misérias e novas metodologias investigatórias. Rio de Janeiro: Lumen Juris, 2011, p. 99. 
que grande parte das ações penais que estão nos fóruns sejam baseadas unicamente em depoimentos de testemunhas que foram prestadas nesta fase, algumas que unicamente "ouviram dizer" algo sobre o fato e outras (ações) que somente tem como "testemunhas" os policiais que atenderam a ocorrência ${ }^{55}$.

Soma-se a isso o discurso da presunção de veracidade das peças de informação do inquérito, com o fundamento de serem produzidas por funcionários públicos e terem "fé pública". Contudo, essa presunção de veracidade gera efeitos contrários a própria natureza do inquérito, levando a que sejam admitidos no processo atos administrativos, sigilosos, não contraditórios e muitas vezes sem o exercício da defesa ${ }^{56}$.

Todos esses fatores acabam contribuindo para a incursão de operadores de contágio, como a confiança ${ }^{57}$ e a presunção de veracidade dos

55 Em pesquisa realizada pela Defensoria Pública do Rio de Janeiro sobre sentenças judiciais em tráfico de drogas na cidade e região metropolitana do Rio de Janeiro, em $62,33 \%$ dos casos o agente policial foi a única testemunha ouvida no processo e em $53,79 \%$ dos casos o depoimento do agente de policial foi a principal prova valorada pelo juiz para sentenciar (DEFENSORIA PÚBLICA DO RIO DE JANEIRO. Pesquisa sobre as sentenças judiciais por tráfico de drogas na cidade e região metropolitana do rio de janeiro, 2017, p. 77. Disponível em: http://www.defensoria.rj.def.br/uploads/arquivos/4fab66cd44ea468d9df83d0913fa8a96.pdf Acessado em 07 de junho de 2018). Isso ainda fica mais evidente com a Súmula 70 do Tribunal de Justiça do Rio de Janeiro que diz que "o fato de restringir-se a prova oral a depoimentos de autoridades policiais e seus agentes não desautoriza a condenação.". Por outro lado, em estudo do Núcleo de Estudos da Violência da Universidade de São Paulo (NEV-USP) sobre flagrantes de tráfico de drogas na cidade de São Paulo, verificou-se que "74\% dos casos contaram apenas com o testemunho dos policiais que realizaram a apreensão do acusado, não estando presente nenhuma outra testemunha civil." (MARQUES DE JESUS, M.G.; HILDEBRAND OI, A.; ROCHA, T.T.; LAGATTA, P. Prisão Provisória e Lei de Drogas: um estudo sobre os flagrantes de tráfico de drogas na cidade de São Paulo. São Paulo: NEV, 2011, p. 55). LOPES JR., Aury; GLOECKNER, Ricardo Jacobsen. Investigação preliminar no processo penal. São Paulo: Saraiva, 2013, p. 302.

57 Aqui a confiança está como uma antecipação do futuro, no mesmo sentido empregado por Luhmann: "Mostrar confianza es antecipar el futuro. Es comportarse como si el futuro fuera cierto. Uno podría decir que a través de la confianza, el tiempo se invalida o al menos se invalidan las diferencias de tiempo" (LUHMANN, Niklas. Confianza. Barcelona: Anthropos; México: Universidad Iberoamericana; Santiago de Chile: Instituto de Sociología, Pontificia Universidad Católica de Chile, 1996, p. 15). 
atos produzidos no inquérito, invertendo a polaridade da carga probatória para a defesa (fulminando a presunção de inocência) e preenchendo expectativas que são normalizadas nesse processo de reconstrução de verdade contaminado pela evidência.

Esse entendimento então faz brotar uma "verdade" presumida advinda do inquérito policial ${ }^{58}$, o que faz com que em conjunto de uma investigação "rápida" estejam ainda no plano da evidência ${ }^{59}$, pois não passaram pelo crivo do contraditório ${ }^{60}$, e preencham as expectativas normativas do senso comum, o que dificulta qualquer possibilidade de constrangimento dos operadores das evidências, tornando assim atos produzidos unilateralmente e de forma obscura com uma inexistente presunção de veracidade, que na prática dificilmente poderá ser derrubada pela defesa ${ }^{61}$.

58 "O inquérito policial, em nossa tradição jurídica, busca alcançar a "verdade real", identificando um culpado responsável pelo que aconteceu. Nessa busca, vale- se de procedimentos inquisitivos e sigilosos, algumas vezes ilegais, mas que se tornaram práticas institucionalizadas de produção da verdade policial (VARGAS, Joana Domingues; RODRIGUES, Juliana Neves Lopes. Controle e cerimônia: o inquérito policial em um sistema de justiça criminal frouxamente ajustado. Revista Sociedade e Estado, vol. 26, n. 1, p. 77-96, jan./abr. 2011, p. 78). Entende-se aqui plano da evidência como aquilo que, por não precisar de justificação, é a exata descrição daquilo que se pensa verdadeiro. Deste modo, corresponde a uma satisfação excessivamente rápida diante dos fatos, instaurando de certa maneira o que Rui Cunha Martins chama de "desamor ao contraditório", típico de sistemas inquisitoriais, já que aquilo que parece notório (evidente) tem por finalidade eliminar o processo em contraditório por meio do célere preenchimento de expectativas desejantes (MARTINS, Rui Cunha. $O$ Ponto Cego do Direito: The Brazilian Lessons. $3^{\text {a }}$ ed. São Paulo: Atlas, 2013, p. 3)

Trata-se aqui o contraditório como uma "técnica de coleta probatória", isto é, o que não for colhido em contraditório não é prova e não pode ser utilizado na fundamentação de decisões judiciais (GLOECKNER, Ricardo Jacobsen. Autoritarismo e Processo Penal: uma genealogia das ideias autoritárias no processo penal brasileiro - vol. 1. Florianópolis: Tirant Lo Blanch, 2018, p. 423).

"Em uma polícia altamente dependente da produção de uma verdade in-corporada, extraída até mesmo à força do corpo do sujeito ou meticulosamente costurada por meio das "perguntas mais adequadas", em depoimentos, seguidas das respostas com uma cautelosa distribuição de ênfases na hora da redução a termo, a evidência é a tônica de sua atuação. Afinal, tanto em sua forma mais brutal - força física - como na mais sutil - escultura linguística - a força policial está presente." (SAMPAIO, André Rocha. Profanando o dispositivo "inquérito policial" e seu ritual de produção de verdades. Revista Brasileira de Ciências Criminais, vol. 134, p. 351-383, 2017, p. 366). 
Agrava-se ainda mais no direito brasileiro o fato do inquérito policial ser escrito e de seus autos serem apensados ao processo e seguirem para conhecimento do julgador ${ }^{62}$, o que acaba se tornando uma espécie de "arquivo oficial" que agrupa todo o discurso policial e fica em stand by pronto para ser utilizado por quem precisar ${ }^{63}$. Juntamente

62 Art. 12. O inquérito policial acompanhará a denúncia ou queixa, sempre que servir de base a uma ou outra. Segundo Chourk essa seria "a mais séria distorção encontrada na realização da nossa justiça penal, qual seja, a indevida intromissão dos elementos de informação coletados durante a investigação na atividade jurisdicional" (CHOUKR, Fauzi Hassan. Garantias constitucionais na investigação criminal. Rio de Janeiro: Lumen Juris, 2006, p. 131). Importante observar que foi sancionado em 24 de dezembro de 2019 a Lei 13.964 que modificou, entre outros, o Código de Processo Penal, trazendo o instituto do juiz das garantias e no $\$ 3^{\circ}$ do art. $3^{\circ}-\mathrm{C}$ aduz que "Os autos que compõem as matérias de competência do juiz das garantias ficarão acautelados na secretaria desse juízo, à disposição do Ministério Público e da defesa, e não serão apensados aos autos do processo enviados ao juiz da instrução e julgamento, ressalvados os documentos relativos às provas irrepetíveis, medidas de obtenção de provas ou de antecipação de provas, que deverão ser remetidos para apensamento em apartado.", modificando o entendimento do acompanhamento do inquérito apensado ao processo. Ocorre que na decisão cautelar proferida nas Ações Diretas de Inconstitucionalidade (ADIs) 6.298, 6.299, 6.300 e 6.305, o Ministro do Supremo Tribunal Federal Luiz Fux suspendeu a eficácia das regras da Lei 13.964/2019 que instituem o juiz de garantias e seus derivados por tempo indeterminado e as regras anteriores ainda estão vigorando.

63 "O ingresso do inquérito policial na fase judicial, autoriza duas consequências, ambas problemáticas desde uma concepção acusatória de processo: a) em primeiro lugar, como corolário indefectível da livre convicção, ao magistrado era facultado julgar tomando-se por base os elementos do inquérito policial. Disso não cabem muitas dúvidas, à medida que tal malabarismo semântico permitiu, inclusive, que nas reformas de 2008, tal circunstância fosse justificada e legalizada, sob a aparência de uma 'evolução' no sentido de proteção das garantias do acusado. O famoso 'cotejo' do inquérito policial com os autos processuais permite, assim, uma condenação baseada no inquérito e que pode ser devidamente 'maquiada' através da adoção, na fundamentação, de trechos, recortes ou quaisquer técnicas de bricolagem na decisão. [...] Contudo, resta ainda a segunda consequência referida como negativa: b) a introdução do inquérito policial no núcleo processual enfraquecerá ou mesmo inviabilizará o exercício do contraditório. E isto por uma razão deveras elementar, compartilhada pelo espírito autoritário de MANZINI: quando se admite que os depoimentos em juízo sejam confrontados com aqueles prestados perante a polícia, a leitura de trechos dos depoimentos, serve para 'refrescar a memória' do depoente, o que significa: reordenar a narrativa, a fim de que ela volte para a história já documentada desde a fase policial; ou ainda, 
com a redação do art. 155 do Código de Processo Penal está formado o "combo" que possibilita as maiores arbitrariedades e enganações às garantias da oralidade e da imediação na formação da prova, dando azo ao que se chama de "falsas oralidades", afinal, "mesmo que não faça menção expressa a algum elemento do inquérito, quem garante que a decisão não foi tomada com base nele?" ${ }^{4}$.

Assim, em análise mais profunda do artigo 155, nota-se que o juiz não poderá fundamentar sua decisão tão-somente no inquérito, porém deixa a possibilidade do magistrado através da "livre apreciação da prova" utilizar, desde que não "exclusivamente", o que foi produzido na fase inquisitória em sua fundamentação da decisão. O que isto significa na realidade é que não existindo prova no processo para sustentar a condenação, abre-se uma brecha $^{65}$ para o juiz se valer do que foi produzido no inquérito.

Nesses moldes, o inquérito policial acaba por conter funções de diferentes domínios em relação a sua finalidade precípua. No domínio das

constranger a testemunha a fim de que ela apenas ratifique os elementos integrados à investigação preliminar.” (GLOECKNER, Ricardo Jacobsen. Autoritarismo e Processo Penal: uma genealogia das ideias autoritárias no processo penal brasileiro - vol. 1. Florianópolis: Tirant Lo Blanch, 2018, p. 421-422).

LOPES JR., Aury Lopes. Fundamentos do processo penal: Introdução crítica. $2^{\mathrm{a}}$ ed. São Paulo: Saraiva, 2016, p. 161. A contaminação gerada pela integração do inquérito policial ou qualquer outra peça produzida sem garantias constitucionais ao processo penal "irradiam efeitos sobre todo o processo penal, com consequências multiplicadoras, acumulativas e retroalimentadoras e nem sempre perceptíveis no momento de sua potencialização" (GIACOMOLLI, Nereu José. A fase preliminar do processo pena. Crises, misérias e novas metodologias investigatórias. Rio de Janeiro: Lumen Juris, 2011, p. 5).

São nessas micro relações (brechas, por exemplo) que residem as potências mais perigosas: "cada fascismo se define por um microburaco negro, que vale por si mesmo e comunica com os outros, antes de ressoar num grande buraco negro central generalizado" (DELEUZE, Gilles; GUATTARI, Félix. Mil Platôs: capitalismo e esquizofrenia. Vol. 3. Tradução Aurélio Guerra Neto, Ana Lúcia de Oliveira, Lúcia Cláudia Leão e Suely Rolnik. São Paulo: Ed. 34, 1996, p. 92). Neste sentido, Amaral percebe uma relação de "microinquisitorialismos" dentro do processo penal, que faz com que haja uma maleabilidade política das provas para adequá-las a determinados interesses. Daí a clareza de "verdades reais" e "evidências" como perigo, colocando qualquer um como juiz e o próprio juiz como justiceiro (AMARAL, Augusto Jobim do. Política da prova e cultura punitiva: a governabilidade do processo penal brasileiro contemporâneo. São Paulo: Almedina, 2014, p. 482). 
funções aparentes, o inquérito acaba sendo um instrumento para apuração da autoria e materialidade do fato criminoso, somente tendo valor para o oferecimento ou não da denúncia. Porém, sua finalidade não termina nas funções aparentes, uma vez que a própria estrutura do CPP brasileiro faz com que se retire do inquérito funções ocultas ou não aparentes ainda mais relevantes na prática ${ }^{66}$. Essas funções ocultas do inquérito ligam-se aos argumentos discursivos utilizados pelo julgador na decisão judicial: busca da verdade e livre convicção. Tais argumentos trazem à mostra a função não aparente mais perversa do inquérito policial: a autorização para o juiz formar sua convicção e sua consequente formulação da decisão em torno dos elementos produzidos no inquérito, fulminando assim com o procedimento em contraditório ${ }^{67}$.

Essa autorização de utilização do inquérito na valoração probatória faz com que o julgador tenha uma precoce conclusão sobre o caso - muitas vezes advindo de um "conjunto de pequenos indícios" contidos naquela peça inquisitorial - que deveria apenas provir da formação da prova em contraditório, invertendo o ônus probatório ao acusado e tornando a presunção de inocência em uma presunção de culpabilidade.

Portanto, o que se revelou desde a mudança de redação do art. 155 do CPP pela Lei 11.690/2008 foi uma grande maquiagem dentro do sistema processual penal brasileiro, pois é certo que não se autoriza (diretamente) uma busca obsessiva da verdade a todo custo, mas a brecha tomada pelo advérbio "exclusivamente" e a gama de excepcionalidade por ele introduzida empurra-o inevitavelmente para uma zona de mera adequação formal, na qual continuar-se-ão sendo assistidas sentenças que buscarão no inquérito policial os elementos necessários para a

66 GLOECKNER, Ricardo Jacobsen. Autoritarismo e Processo Penal: uma genealogia das ideias autoritárias no processo penal brasileiro - vol. 1. Florianópolis: Tirant Lo Blanch, 2018, p. 394-395.

67 Gomes Filho lembra que na Itália apesar do último parágrafo do art, 349 do Código de Processo Penal italiano vedar que o juiz tivesse informações advindas da peça policial, na prática esses dados eram incluídos na comunicação escrita e acabavam sendo utilizados na decisão judicial diante de uma concepção muito ampla do princípio do livre convencimento, determinada na praxe dos tribunais (GOMES FILHO, Antonio Magalhães. Direito à Prova no Processo Penal. Imprenta: São Paulo: Revista dos Tribunais, 1997, p. 66). 
condenação ${ }^{68}$. Deste modo, pode-se afirmar que o CPP se incumbiu de construir um sistema que dispensaria o contraditório futuro, ao passo que os elementos que verdadeiramente importam à uma decisão futura são produzidos na fase de investigação preliminar, que depois são retoricamente legitimados judicialmente, o que Gloeckner chamou de contraditório deformado ${ }^{69}$.

Além do mais esse entendimento é verdadeira vertente jurisprudencial nos Tribunais brasileiros, no qual se confunde prova com meio de prova e com naturalidade é vista a possibilidade da mescla dos dados colhidos no inquérito na ação penal, que sem a incidência do contraditório transforma o processo penal em algo disforme, onde o Estado-jurisdição cede espaço ao Estado-administração e termina por servir como apoio para o provimento de uma sentença condenatória ${ }^{70}$.

68 CUNHA MARTINS, Rui. O Ponto Cego do Direito: The Brazilian Lessons. $3^{\mathrm{a}}$ ed. São Paulo: Atlas, 2013, p. 23. Segundo Lopes JR.: "A fraude reside no fato de que a prova é colhida na inquisição do inquérito, sendo trazida integralmente para dentro do processo e, ao final, basta o belo discurso do julgador para imunizar a decisão. Esse discurso vem mascarado com as mais variadas fórmulas, do estilo: a prova do inquérito é corroborada pela prova judicializada; cotejando a prova policial com a judicializada; e assim todo um exercício imunizatório (ou, melhor, uma fraude de etiquetas) para justificar uma condenação, que, na verdade, está calcada nos elementos colhidos no segredo da inquisição. O processo acaba por converter-se em uma mera repetição ou encenação da primeira fase" (LOPES JR., Aury Lopes. Fundamentos do processo penal: Introdução crítica. $2^{\text {a }}$ ed. São Paulo: Saraiva, 2016, p.162).

69 Segundo o autor, "a tríade "liberdade das provas, livre convencimento judicial e verdade real' continua sendo adotada em nível doutrinário e jurisprudencial. As reformas não alteraram pontos significativos relativamente a tais questões, mantendo-se exatamente o mesmo núcleo do código de 1941. Em decorrência da intromissão de elementos elaborados na fase de investigação na fase judicial, autorizada a leitura e o confronto com as testemunhas em juízo, tem-se a manutenção de um contraditório deformado. O nível de rechaço ao contraditório pode ser visualizado inclusive nas diversas relativizações sustentadas pelos tribunais à plena aplicação do sistema de exame cruzado, que, quando desrespeitado, se tornou uma modalidade de "nulidade relativa'". (GLOECKNER, Ricardo Jacobsen. Autoritarismo e Processo Penal: uma genealogia das ideias autoritárias no processo penal brasileiro - vol. 1. Florianópolis: Tirant Lo Blanch, 2018, p. 465).

${ }^{70}$ CHOUKR, Fauzi Hassan. Garantias constitucionais na investigação criminal. Rio de Janeiro: Lumen Juris, 2006, p. 134. 
Dessa forma, com essa redação do art. 155 do CPP dada pela Lei 11.690/2008, "perdeu-se a oportunidade de encarar frontalmente os reflexos na eficácia probatória dos ditos atos de investigação"71. Aqui entra em cena a importante diferença entre meros atos de investigação e atos verdadeiramente de prova. Assim, são considerados atos de prova aqueles que: (a) estão dirigidos a convencer o juiz da verdade de uma afirmação; (b) estão a serviço do processo e integram o processo penal; (c) dirigem-se a formar um juízo de certeza - tutela de segurança; (d) servem à sentença; (e) exigem estrita observância da publicidade, contradição e imediações; (f) são praticados ante o juiz que julgará o processo.

Por outro lado, os atos de investigação: (a) não se referem a uma afirmação, mas a uma hipótese; (b) estão a serviço da investigação preliminar, isto é, da fase pré-processual e para o cumprimento de seus objetivos; (c) servem para formar um juízo de probabilidade, e não de certeza; (d) não exigem estrita observância da publicidade, contradição e imediações, pois podem ser restringidas; (e) servem para a formação da opinio delicti do acusador; (f) não estão destinados a sentença, mas a demonstrar a probabilidade do fumus commissi delicti para justificar o processo (recebimento da ação penal) ou o não-processo (arquivamento); (g) também servem de fundamento para decisões interlocutórias de imputação (indiciamento) e adoção de medidas cautelares pessoais, reais ou outras restrições de caráter provisional; (h) podem ser praticados pelo Ministério Público ou pela Polícia Judiciária ${ }^{72}$.

Com essa distinção, a doutrina coloca os atos de investigação, como regra geral, somente com valor endoprocedimental para a justificação do início ou não do processo ou para servir de base para alguma medida cautelar pessoal (prisões provisórias, por exemplo) ou real (arresto, sequestro) ${ }^{73}$.

71 AMARAL, Augusto Jobim do. Política da prova e cultura punitiva: a governabilidade do processo penal brasileiro contemporâneo. São Paulo: Almedina, 2014, p. 444.

72 LOPES JR., Aury. Direito processual penal. $14^{\mathrm{a}}$ ed. São Paulo: Saraiva, 2017, p. 158-159.

73 LOPES JR., Aury; GLOECKNER, Ricardo Jacobsen. Investigação preliminar no processo penal. São Paulo: Saraiva, 2013, p. 322. 
Importante observar que as provas repetíveis ou renováveis têm valor meramente informativo - ou de atos de investigação. Essas provas renováveis, como a prova testemunhal, acareações, reconhecimentos etc., para poderem ser valoradas na decisão devem ser necessariamente produzidas na fase processual, no debate em contraditório na presença do juiz que julgará o caso (imediação) e com plena observância dos critérios de forma que regem a produção da prova penal ${ }^{74}$.

Deste modo, os atos praticados durante o inquérito policial brasileiro, ressalvados aqueles que não podem ser repetidos ${ }^{75}$ (mas devem ser produzidos mediante o instituto da produção antecipada de provas), somente originam atos de investigação, por serem praticados de uma forma tipicamente inquisitiva, baseada, principalmente, na ausência ou limitação do contraditório, o que faz com que (em tese) não possam ser valorados na decisão do julgador ${ }^{76}$.

Aqui, por repetição ou renovação entendemos uma nova realização ou declaração de algo que já se fez ou se disse, ou seja, que a pessoa que originalmente produziu o ato volte a realizá-lo. Com isso, não configura repetição ou renovação a simples leitura do testemunho anteriormente praticado $^{77}$, sendo isto considerado reprodução e não repetição e a única

74 LOPES JR., Aury. Direito processual penal. 14a ed. São Paulo: Saraiva, 2017, p. 161.

75 "A característica de não-repetição do ato [...] é que autoriza a colocação em pauta do tema do contraditório já na fase prévia à ação penal, raciocinandose que não poderá haver um pleno direito de defesa se não for possibilitada a intervenção do suspeito já desde esse momento [...]" (CHOUKR, Fauzi Hassan. Garantias constitucionais na investigação criminal. Rio de Janeiro: Lumen Juris, 2006, p. 132).

76 LOPES JR., Aury; GLOECKNER, Ricardo Jacobsen. Investigação preliminar no processo penal. São Paulo: Saraiva, 2013, p. 322. Nesse sentido Giacomolli: "prova é o que foi produzido sob o crivo do contraditório. É na produção da prova que o contraditório, com a participação dos destinatários e seus efeitos, mormente o acusado, ganha relevância. O que estiver despido de contraditório, não é ato probatório, podendo constituir-se em ato de investigação" (GIACOMOLLI, Nereu José. Reformas (?) do processo penal: considerações críticas. Rio de Janeiro: Lumen Juris, 2008, p. 21-22).

77 A leitura dos elementos produzidos na investigação é mais uma herança advinda do Code d'Istruction Criminelle que admitia a leitura dos termos, presente ou não a testemunha. Segundo afirma Cordero se fosse do interesse de quem acusava, ele poderia afastar suas testemunhas do contraditório, 
reprodução processualmente válida é a que deriva de uma produção antecipada de provas que foi cercada de todas as garantias fundamentais do acusado e jurisdicionais, como o contraditório ${ }^{78}$.

Por outro lado, não se pode considerar repetição a simples ratificação do depoimento anteriormente prestado na fase de investigação (chamado de "dar por lido"), pois a testemunha não só deve comparecer como também declarar sobre o fato (binômio presença física e oralidade), afinal não se pretende um contraditório ratificador, mas um contraditório efetivo produzido por meio da produção da prova durante o debate e perante o julgador da causa ${ }^{79}$. Assim, a oralidade garante a imediação e faz com que o julgador tenha contato direto com a formação da prova e mantenha a plena cognitio para que ao final possa valorá-la e julgar ${ }^{80}$.

Portanto, como assevera Giacomolli:

mantendo seus depoimentos prestados anteriormente acessível aos jurados de forma direta ou por meio de leitura (CORDERO, Franco. Guida alla procedura penale. Torino: UTET, 1986, p. 74).

Deve-se lembrar que em regra, a prova testemunhal pode ser repetida em juízo e somente excepcionalmente, diante do risco de perecimento e do grave prejuízo que significa a perda de alguns dos elementos recolhidos no inquérito, é que o processo penal instrumentaliza uma forma de colher de forma antecipada essa prova. Portanto, o incidente de produção antecipada de provas somente pode ser admitido em casos extremos, em que se foi demonstrado que existe uma grande probabilidade de que será impossível a repetição do ato na fase processual. No caso da prova testemunhal, é importante que seja fielmente reproduzida, utilizando-se dos melhores meios disponíveis para isso, sobretudo os não escritos, tais quais a filmagem e a gravação (LOPES JR., Aury; GLOECKNER, Ricardo Jacobsen. Investigação preliminar no processo penal. São Paulo: Saraiva, 2013, p. 328-329).

79 Segundo Gloeckner: “Os depoimentos contidos na fase policial servem como elementos para ditar limitações à oralidade e à imediatidade da prova. Sendo o contraditório um método, tal método é falho quando elementos escritos servem para transformar oralidade e imediatidade em testemunhos ratificatórios, o que consiste na transformação da fase judicial em uma pantomima, em uma teatralização dos elementos previamente recolhidos ou, como afirma Cordero, em um campeonato de oratória." (GLOECKNER, Ricardo Jacobsen. Autoritarismo e Processo Penal: uma genealogia das ideias autoritárias no processo penal brasileiro - vol. 1. Florianópolis: Tirant Lo Blanch, 2018, p. 423).

80 LOPES JR., Aury; GLOECKNER, Ricardo Jacobsen. Investigação preliminar no processo penal. São Paulo: Saraiva, 2013, p. 326. 
o juízo condenatório não poderá assentar-se em elementos informativos da investigação, com ressalvas das situações de antecipação, de cautelaridade e de provas não renováveis (possibilidade de serem produzidas em determinado marco temporal). Isso porque a função da investigação é fornecer elementos de convicção ao acusador, ao exercício da ação penal e não de um juízo condenatório, ao magistrado ${ }^{81}$.

Com as mudanças advindas com a Lei 13.964/2019, o que devese observar é se (ou como) os magistrados ainda continuarão de alguma forma utilizando o inquérito para fundamentar suas decisões e uma das principais burlas a esse sistema poderá advir das leituras e ratificações dos depoimentos prestados na fase de investigação ${ }^{82}$. Cabe(ria) aos juízes de instrução não aceitar essas burlas, contudo sabe-se que a legislação por si só não muda a mentalidade dos atores processuais e nossa cultura inquisitória vive de ressignificar conceitos para se adequar aos interesses de um processo penal inquisitorial.

Dessa forma, será interessante verificar como o art. 155 do CPP se comportará depois dessa lei, pois a "livre apreciação da prova" consolida o contraditório como disciplina da prova, porém o advérbio "exclusivamente" continua lá abrindo a brecha para os magistrados basearem-se no inquérito policial, com fundamento na sua "livre convicção" ${ }^{83}$. Manteve-se, contudo, a autorização legal para que juízes e tribunais utilizem

81 GIACOMOLLI, Nereu José. A fase preliminar do processo pena. Crises, misérias e novas metodologias investigatórias. Rio de Janeiro: Lumen Juris, 2011, p. 100.

$82 \mathrm{O}$ próprio $\S 4^{\circ}$ do art. $3^{\circ}-\mathrm{C}$ da Lei $13.964 / 2019$ aduz que fica assegurado às partes o amplo acesso aos autos acautelados na secretaria do juízo das garantias. Não há dúvidas que tais elementos podem ser utilizados em ações autônomas impugnativas por exemplo, mas com o art. 155 do CPP em vigência e a mentalidade inquisitória dos atores jurídicos, qual o óbice da utilização destes elementos para suprir eventual deficiência probatória da acusação? (DEZEM, Guilherme Madeira; SOUZA, Luciano Anderson de. Comentários ao Pacote Anticrime: Lei 13.964/2019. São Paulo: Revista dos Tribunais, 2020, p. 93).

83 Esse caráter de brecha empurra para o que Cunha Martins chama de uma zona estratégica de mera adequação formal ou "mera cosmética", de forma a consagrar a deturpação da democraticidade do processo (CUNHA MARTINS, Rui. O Ponto Cego do Direito: The Brazilian Lessons. $3^{\text {a }}$ ed. São Paulo: Atlas, 2013, p. 31). 
a versão dissimulada de "condenar com base na prova judicial cotejada com a do inquérito", ou, de forma mais verdadeira, "não existe prova no processo para sustentar a condenação, de modo que vou me socorrer do que está no inquérito"84.

Assim, de um lado, no art. 155 o contraditório é posto como condição de validade probatória ${ }^{85}$, com uma íntima relação com a imediação, isto é, só poderão ser valoradas pelo julgador em sua decisão as provas que são produzidas no debate oral, na sua presença e com a efetiva participação das partes.

Porém, por outro lado, pode-se então afirmar que, para além dos argumentos da livre convicção e da verdade real, o "operador adverbial referido ["exclusivamente"] é que possibilita o contágio com a carga alucinatória dos atos de investigação sempre postos para rapidamente satisfazer e dar suporte à decisão" ${ }^{\text {. }}$. Dessa forma, pouco adiantará uma estrutura dialética de um procedimento em contraditório com uma (aparente) imediação se existir essa burla interna de abrir um espaço, mesmo que mínimo, para que os atos de investigação possam compor o convencimento do magistrado.

Para que ocorra então essa originalidade cognitiva do julgador é elogiável a técnica adotada em alguns sistemas processuais como o italiano de eliminar dos autos que formarão o processo penal todas as peças da investigação preliminar, com exceção do corpo de delito e das provas antecipadas, com o objetivo de evitar a contaminação do juiz pelos elementos produzidos nesta fase pré-processual, bem como a implementação do juiz das garantias, que com a Lei 13.964/2019 foram adotados aqui no Brasil, apesar de estarem suspensos por tempo indeterminado.

84 LOPES JR., Aury. Direito processual penal. $14^{\mathrm{a}}$ ed. São Paulo: Saraiva, 2017, p. 165.

85 Gomes Filho chega a afirmar que o contraditório é a pedra angular da nova disciplina de prova (GOMES FLHO, Antônio Magalhães. "Provas - Le 11.690, de 09.06.2008”. In ASSIS MOURA, Maria Teresa Rocha de (Coord.). As Reformas no Processo Penal: As novas leis de 2008 e os Projetos de Reforma. São Paulo: RT, 2008, p. 249.

86 AMARAL, Augusto Jobim do. Política da prova e cultura punitiva: a governabilidade do processo penal brasileiro contemporâneo. São Paulo: Almedina, 2014, p. 446. 
Ocorre que se entende que apenas isso não basta, uma vez que o que tem que mudar é a mentalidade e a cultura inquisitória enraizada nos atores processuais penais, pois apenas mudar a legislação ocorrerá o que Alberto Binder chama de "fetichismo normativo". Temos de início que modificar nossa estrutura como um todo, que ainda tem núcleo inquisitório, bem como criar meios eficazes para que tenhamos uma cultura calcada no contraditório como a única técnica de coleta probatória que o julgador possa utilizar em sua decisão.

\section{Considerações Finais}

Ao longo do artigo verificou-se que a América Latina teve seu processo penal originário dos países da Europa continental, especialmente dos países ibéricos, e com isso herdou características inquisitoriais. No Brasil, de forma genérica, a maior parte da legislação penal e processual penal que vigorou até sua independência estava prevista nas Ordenações portuguesas, mais especificamente no Livro V das Ordenações Filipinas. Com isso, de forma geral, o processo penal da América Latina foi dividido em duas fases principais: a fase de investigação (resumo ou instrução) e a fase de veredito ou sentença (plenário ou julgamento).

Nessa época ambas as fases eram escritas e a espinha dorsal do processo eram os chamados dossiês ou expedientes que a polícia e o juiz de instrução reuniam. Esse instrumento documentava toda a atividade do processo, abarcando além das provas documentais as provas testemunhais, periciais etc., que seriam utilizadas pelos julgadores na fase de julgamento. Essa tradição inquisitorial cria uma cultura inquisitória típica dos países latino-americanos, que mesmo influenciados por algumas ideias republicanas, mantiveram suas características principais: procedimento escrito e secreto; uma administração da justiça secreta; um procedimento com pouco respeito ao imputado, já que ele é objeto da investigação; a desnaturalização da fase de juízo, uma vez que o procedimento se converte em dossiês ou expedientes e a parte mais importante é a fase de investigação; a delegação das funções judiciais para empregados subalternos, já que a sobrecarga de trabalho impede que o juiz possa atender todos os casos. 
No Brasil, a herança de uma forte cultura inquisitória coloca a investigação como o centro da produção probatória, o que faz com que o Ministério Público pouco acrescente em juízo ao que foi produzido no inquérito, fazendo com que apenas haja uma ratificação judicial e transformando o processo em apêndice da investigação. Além disso, tem-se no Brasil uma peculiar formação nas polícias, dividindo-se as funções investigativas e ostensivas entre as chamadas Polícia Civil e Polícia Militar, o que expõe o ranço autoritário permanecente do período de ditadura militar no Brasil. Essa militarização das funções do policiamento ostensivo que põe a Polícia Militar como força auxiliar e de reserva do Exército ilustra a herança mantida dos tempos ditatoriais. Por outro lado, não se pode esquecer das práticas não menos autoritárias, porém mais subterrâneas, da Polícia Civil na busca incessante da "verdade" da infração penal.

Ademais, pode-se considerar praticamente pacificado na doutrina processual penal que o inquérito policial é um sistema falido que não cumpre com sua função principal de esclarecer com grau de probabilidade a notícia-crime para fundamentar o processo e que, portanto, os atos praticados durante ele, apesar de serem importantes para o início ou não da ação penal, não devem servir como juízo de certeza na hora de valorar a condenação ou absolvição do acusado na sentença.

Essa ineficácia do inquérito faz com que grande parte das ações penais que estão nos fóruns de todo o Brasil sejam baseadas unicamente em depoimentos de testemunhas que foram prestadas nesta fase, algumas que unicamente "ouviram dizer" algo sobre o fato e outras (ações) que somente tem como "testemunhas" os policiais que atenderam a ocorrência. Agrava-se ainda mais no direito brasileiro o fato do inquérito policial ser escrito e de seus autos serem apensados ao processo e seguirem para conhecimento do julgador (apesar de agora não ser proibido pela Lei 13.964/2019), o que acaba se tornando uma espécie de "arquivo oficial" que agrupa todo o discurso policial e fica em stand by pronto para ser utilizado por quem precisar. Junto a isso, tem-se o art. 155 do CPP que possibilita as maiores arbitrariedades em relação a formação probatória em um processo oral, uma vez que o juiz pode fundamentar sua decisão nos atos produzidos no inquérito, desde que não "exclusivamente", que 
significa que não existindo provas para sustentar a condenação, o juiz pode se valer do inquérito.

Nesses moldes, o inquérito policial acaba por conter funções de diferentes domínios em relação a sua finalidade precípua. No domínio das funções aparentes, o inquérito acaba sendo um instrumento para apuração da autoria e materialidade do fato criminoso, somente tendo valor para o oferecimento ou não da denúncia. Porém, sua finalidade não termina nas funções aparentes, uma vez que a própria estrutura do CPP brasileiro faz com que se retire do inquérito funções ocultas ou não aparentes ainda mais relevantes na prática. Essas funções ocultas do inquérito ligam-se aos argumentos discursivos utilizados pelo julgador na decisão judicial: busca da verdade e livre convicção. Tais argumentos trazem à mostra a função não aparente mais perversa do inquérito policial: a autorização para o juiz formar sua convicção e sua consequente formulação da decisão em torno dos elementos produzidos no inquérito, fulminando assim com o procedimento em contraditório.

Interessante será observar na prática como será posto o juiz das garantias trazido pela Lei 13.964/2019, bem como a proibição do inquérito de acompanhar o processo, afinal não adianta mudar as leis se a mentalidade dos atores processuais continuarem inquisitórias. Além disso, a histórias do nosso processo penal é de ressignificações de institutos para se adequarem ao nosso autoritarismo processual penal, lembrando ainda que o próprio Código de Processo Penal continua em sua essência inquisitório com alguns remendos de processo acusatório, com a doutrina e os tribunais compactuando com essa essência.

\section{REFERÊNCIAS}

AMARAL, Augusto Jobim do. Política da prova e cultura punitiva: a governabilidade do processo penal brasileiro contemporâneo. São Paulo: Almedina, 2014.

AMARAL, Augusto Jobim do. A ostensividade da soberania policial. In: GLOECKNER, R. J.; FRANÇA, L. A.; RIGON, B. S (Orgs.). Biopolíticas: Estudos sobre política, governamentalidade e violência. Curitiba: iEA Academia, 2015.

AMARAL, Augusto Jobim do e ROSA, Alexandre Morais da. Cultura da Punição: a ostentação do horror. ed. 3. Florianópolis: Empório do Direito, 2017. 
AMARAL, Augusto Jobim do. "Mal de Polícia" - À propósito de uma criminologia radical. Revista Brasileira de Ciências Criminais, v. 111, p. 263-291, São Paulo: RT, nov./dez., 2014.

ANISTIA INTERNACIONAL. Você matou meu filho!: homicídios cometidos pela polícia militar na cidade do Rio de Janeiro. Rio de Janeiro: Anistia Internacional, 2015.

ÁVILA, Thiago André Pierobom de. O controle pelo ministério público das Políticas de segurança pública. In: Conselho Nacional do Ministério Público. O Ministério Público e o controle externo da Atividade Policial: Dados 2016. Brasília: CNMP, 2017.

BATISTA, Nilo. Matrizes ibéricas do sistema penal brasileiro. Rio de Janeiro: Revan, 2000.

BERCOVICI, Gilberto. "O direito constitucional passa, o direito administrativo permanece”: a persistência do direito administrativo de 1967. In: TELES, Edson; SAFATLE, Vladimir (Org.). O que resta da ditadura: a exceção brasileira. São Paulo: Boitempo, 2010.

BINDER, Alberto M. La justicia penal en la transición a la democracia en américa latina. Alicante: Biblioteca Virtual Miguel de Cervantes, 2005.

BINDER, Alberto La fuerza de la Inquisición y la debilidad de la República. Política Criminal Bonaerense, n. 1, 2003.

CERQUEIRA, Carlos Magno Nazareth. Questões preliminares para a discussão de uma proposta de diretrizes constitucionais sobre a segurança pública. Revista Brasileira de Ciências Criminais, v. 22, p. 139-181, São Paulo: RT, abr./jun., 1998.

CHOUKR, Fauzi Hassan. Inquérito policial: novas tendências e práticas. Boletim IBCCRIM, São Paulo, v. 84, novembro, 1999.

CHOUKR, Fauzi Hassan. Transição e consolidação da democracia: instrumentos, práticas e limitações na experiência brasileira. Florianópolis: Empório do Direito, 2016.

CHOUKR, Fauzi Hassan. Garantias constitucionais na investigação criminal. Rio de Janeiro: Lumen Juris, 2006.

CORDERO, Franco. Guida alla procedura penale. Torino: UTET, 1986.

CORDERO, Franco. Procedimiento Penal. Tomo I. Bogotá: Editorial Temis, 2000.

CUNHA MARTINS, Rui. O Ponto Cego do Direito: The Brazilian Lessons. $3^{\mathrm{a}}$ ed. São Paulo: Atlas, 2013. 
D’ELIA FILHO, Orlando Zaccone. Indignos de vida: a forma jurídica da política de extermínio de inimigos na cidade do Rio de Janeiro. Rio de Janeiro: Revan, 2015.

DEFENSORIA PÚBLICA DO RIO DE JANEIRO. Pesquisa sobre as sentenças judiciais por tráfico de drogas na cidade e região metropolitana do rio de janeiro, 2017, p. 77. Disponível em: <http://www.defensoria.rj.def.br/uploads/arquivos/4fab66cd44ea468d9df83d0913fa8a96.pdf> Acessado em 07 de junho de 2018.

DELEUZE, Gilles; GUATTARI, Félix. Mil Platôs: capitalismo e esquizofrenia. Vol. 3. Tradução Aurélio Guerra Neto, Ana Lúcia de Oliveira, Lúcia Cláudia Leão e Suely Rolnik. São Paulo: Ed. 34, 1996.

DEZEM, Guilherme Madeira; SOUZA, Luciano Anderson de. Comentários ao Pacote Anticrime: Lei 13.964/2019. São Paulo: Revista dos Tribunais, 2020.

FERRAJOLI, Luigi. Direito e Razão: teoria do garantismo penal. Revista dos Tribunais, 2002.

FIGUEIREDO DIAS, Jorge; COSTA ANDRADE, Manuel. Criminologia - O Homem Delinquente e a Sociedade Criminógena. Coimbra, 1992.

FOUCAULT, Michel. Em Defesa da Sociedade. São Paulo: Martins Fontes, 2010.

FOUCAULT, Michel. Vigiar e Punir: história da violência nas prisões. $38^{\mathrm{a}} \mathrm{ed}$. Rio de Janeiro: Vozes, 2010.

GHIRINGHELLI DE AZEVEDO, Rodrigo; VASCONCELLOS, Fernanda Bestetti. O Inquérito Policial em Questão - Situação atual e a percepção dos Delegados de Polícia sobre as fragilidades do modelo brasileiro de investigação criminal. Revista Sociedade e Estado - Volume 26 Número 1 Janeiro/Abril, 2011. https:// doi.org/10.1590/S010269922011000100004

GIACOMOLLI, Nereu José. Reformas (?) do processo penal: considerações críticas. Rio de Janeiro: Lumen Juris, 2008.

GIACOMOLLI, Nereu José. A fase preliminar do processo penal. Crises, misérias e novas metodologias investigatórias. Rio de Janeiro: Lumen Juris, 2011.

GLOECKNER, Ricardo Jacobsen. Autoritarismo e Processo Penal: uma genealogia das ideias autoritárias no processo penal brasileiro - vol. 1. Florianópolis: Tirant Lo Blanch, 2018, p. 423).

GLOECKNER, Ricardo Jacobsen; GONÇALVES, Paula Garcia. Letalidade policial e Ministério Público: das práticas de extermínio ao discurso legitimador. Revista Brasileira de Ciências Criminais, v. 130, p. 177-200, São Paulo: RT, abr., 2017. 
GOMES FLHO, Antônio Magalhães. "Provas - Le 11.690, de 09.06.2008”. In ASSIS MOURA, Maria Teresa Rocha de (Coord.). As Reformas no Processo Penal: As novas leis de 2008 e os Projetos de Reforma. São Paulo: RT, 2008.

LANGER, Máximo. Revolução no processo penal latino-americano: difusão de ideias jurídicas a partir da periferia. Revista da Faculdade de Direito da UFRGS, n. 37, p. 4-51, 2017. https://doi.org/10.22456/0104-6594.79266

LEMGRUBER, Julita; MUSUMECI, Leonarda; CANO, Ignacio. Quem vigia os vigias? um estudo sobre controle externo da polícia no Brasil. Rio de Janeiro: Record, 2003.

LOPES JR., Aury. Direito processual penal. 14ª ed. São Paulo: Saraiva, 2017.

LOPES JR., Aury; GLOECKNER, Ricardo Jacobsen. Investigação preliminar no processo penal. São Paulo: Saraiva, 2013.

LUHMANN, Niklas. Confianza. Barcelona: Anthropos; México: Universidad Iberoamericana; Santiago de Chile: Instituto de Sociología, Pontificia Universidad Católica de Chile, 1996.

MAIER, Julio B. J. Situación de la justicia penal y problemas de los sistemas escritos. Revista de la Asociación de Ciencias Penales de Costa Rica, junio 1991, nº 4.

MAIER, Julio B. J. Derecho procesal penal. Tomo I: fundamentos. Buenos Aires: Del Puerto, 2006.

MARQUES, José Frederico. Tratado de direito processual penal. v. 1. São Paulo: Saraiva, 1980.

MARQUES DE JESUS, M.G.; HILDEBRAND OI, A.; ROCHA, T.T.; LAGATTA, P. Prisão Provisória e Lei de Drogas: um estudo sobre os flagrantes de tráfico de drogas na cidade de São Paulo. São Paulo: NEV, 2011.

MISSE, Michel. O Papel do Inquérito Policial no Processo de Incriminação no Brasil: algumas reflexões a partir de uma pesquisa. Revista Sociedade e Estado Vol. 26, n.1, Jan./Abr. 2011. https://doi.org/10.1590/S0102-69922011000100002

MISSE, Michel. O inquérito policial no Brasil. DILEMAS: Revista de Estudos de Conflito e Controle Social - Vol. 3 - no 7 - jan./fev./mar., p. 35-50, 2010.

MISSE, Michel; GRILLO, Carolina Christoph; TEIXEIRA, César Pinheiro; NERI, Natasha Elbas. Quando a polícia mata: homicídios por "autos de resistência” no Rio de Janeiro (2001-2011). Rio de Janeiro: NECVU; BOOKLINK, 2013.

OLIVEIRA, Luciano. Do nunca mais ao eterno retorno: uma reflexão sobre a tortura. $2^{\mathrm{a}}$ ed. São Paulo: Editora Brasiliense, 2009. 
PIERANGELLI, José Henrique. Processo penal: evolução histórica e fontes legislativas. Bauru: Jalovi, 1983.

PINHEIRO, Paulo Sérgio. Autoritarismo e transição. Revista USP, mar.-abr.-maio 1991.

POLI, Camilin Marcie de. O Inquérito Policial e sua utilização na fase processual penal: (des)conformidade com o devido processo penal. $213 \mathrm{f}$. Dissertação (Mestrado em Direito) - Programa de Pós-Graduação em Direito, Setor de Ciências Jurídicas, Universidade Federal do Panará, Curitiba, 2015.

POSTIGO, Leonel González. Bases da reforma processual penal no Brasil: lições a partir da experiência na América Latina. In: COUTINHO, Jacinto Nelson de Miranda; COSTA DE PAULA, Leonardo; NUNES DA SILVEIRA, Marco Aurélio. Mentalidade inquisitória e processo penal no Brasil. O sistema acusatório e a reforma do CPP no Brasil e na América Latina - vol. 3. Florianópolis: Empório do Direito, 2017.

SAMPAIO, André Rocha. Um dispositivo chamado "Inquérito Policial". Boletim Informativo IBRASPP - Ano 03, nº 05, p. 39-41, 2013.

SAMPAIO, André Rocha. Profanando o dispositivo “inquérito policial” e seu ritual de produção de verdades. Revista Brasileira de Ciências Criminais, vol. 134, p. 351-383, 2017.

SCARANCE FERNANDES, Antonio. Teoria Geral do Procedimento e O Procedimento no Processo Penal. São Paulo: Editora Revista dos Tribunais, 2005.

SCHUNEMANN, Bernd. La Reforma del Proceso Penal. Madrid: Dykinson, 2005.

SYKES, Gresham M.; MATZA, David. Techniques of Neutralization: A Theory of Delinquency. American Sociological Review, Vol. 22, No. 6, p. 664-670, Dec., 1957.

VARGAS, Joana Domingues; RODRIGUES, Juliana Neves Lopes. Controle e cerimônia: o inquérito policial em um sistema de justiça criminal frouxamente ajustado. Revista Sociedade e Estado, vol. 26, n. 1, p. 77-96, jan./abr. 2011. https:// doi.org/10.1590/S010269922011000100005

ZAVERUCHA, Jorge. Relações civil-militares: o legado autoritário da Constituição brasileira de 1988. In: TELES, Edson; SAFATLE, Vladimir (Org.). O que resta da ditadura: a exceção brasileira. São Paulo: Boitempo, 2010. 


\section{Informações adicionais e declarações dos autores (integridade cientifica)}

Declaração de conflito de interesses (conflict of interest declaration): o autor confirma que não há conflitos de interesse na realização das pesquisas expostas e na redação deste artigo.

Declaração de autoria e especificação das contribuições (declaration of authorship): todas e somente as pessoas que atendem os requisitos de autoria deste artigo estão listadas como autores; todos os coautores se responsabilizam integralmente por este trabalho em sua totalidade.

Declaração de ineditismo e originalidade (declaration of originality): o autor assegura que o texto aqui publicado não foi divulgado anteriormente em outro meio e que futura republicação somente se realizará com a indicação expressa da referência desta publicação original; também atesta que não há plágio de terceiros ou autoplágio.

Dados do processo editorial (http://www.ibraspp.com.br/revista/index.php/RBDPP/about/editorialPolicies)

- Recebido em: 25/12/2019

- Controle preliminar e verificação de plágio:

- Avaliação 1: 13/03/2020

- Avaliação 2: 16/03/2020

- Decisão editorial preliminar: 25/03/2020

- Retorno rodada de correções 1: 05/04/2020

- Decisão editorial final: 10/04/2020

\section{Equipe editorial envolvida}

- Editor-chefe: 1 (VGV)

- Editor-assistente: 1 (RDG)

- Revisores: 2 


\section{COMO CITAR ESTE ARTIGO:}

MELO, Marcos Eugênio Vieira. Neoinquisitorialismo processual penal e a contaminação do julgador com os atos de investigação: a burla interna no processo penal brasileiro como obstáculo ao contraditório. Revista Brasileira de Direito Processual Penal, Porto Alegre, vol. 6, n. 2, p. 951-992, mai./ago. 2020. https://doi.org/10.22197/rbdpp.v6i2.314 